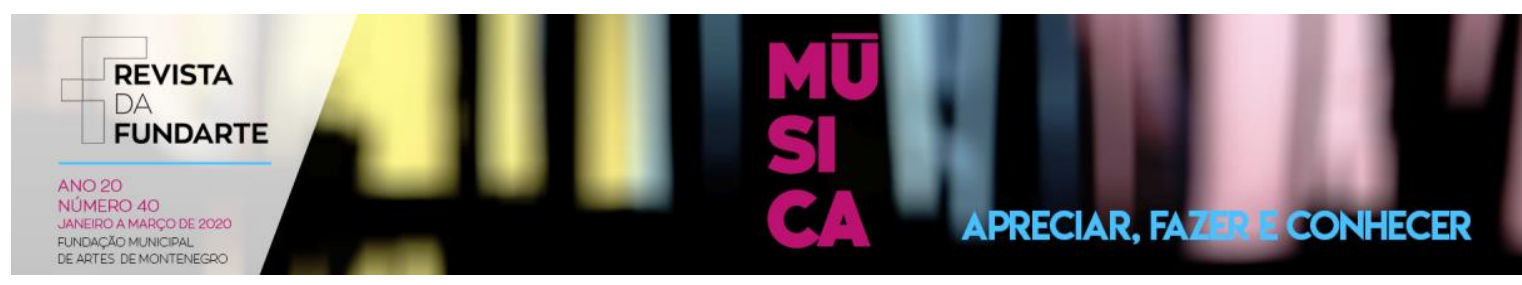

\title{
A MÚSICA COMO INSPIRAÇÃO POÉTICA PARA A CRIAÇÃO: RELATOS SOBRE A MONTAGEM DO ESPETÁCULO "DANÇAR AS COISAS DO PAGO"
}

\author{
Mônica Corrêa de Borba Barboza \\ Mara Rubia Alves \\ Afonso Machado Grecco
}

DOI: http://dx.doi.org/10.19179/2F2319-0868/2F766

BARBOZA, Mônica Corrêa de Borba; ALVES, Mara Rubia; GRECCO, Afonso Machado. A música como inspiração poética para a criação: relatos sobre a montagem do espetáculo "Dançar as coisas do Pago". Revista da FUNDARTE. Montenegro, p.189-214, ano 20, oㅡ 40, janeiro/março de 2020.

Disponível em: http://.seer.fundarte.rs.gov.br/index.php/RevistadaFundarte/index> 31 de março de 2020. 


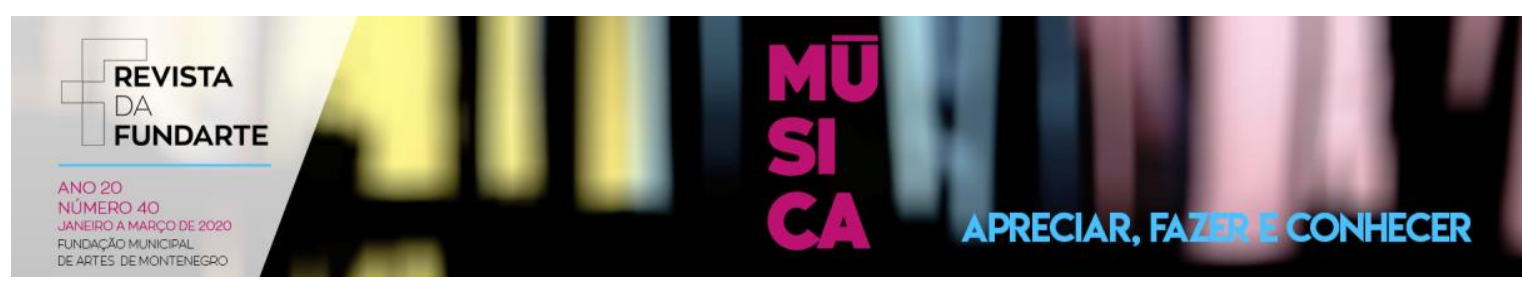

\title{
A MÚSICA COMO INSPIRAÇÃO POÉTICA PARA A CRIAÇÃO: RELATOS SOBRE A MONTAGEM DO ESPETÁCULO "DANÇAR AS COISAS DO PAGO”
}

\author{
Mônica Corrêa de Borba Barboza ${ }^{1}$ \\ Mara Rubia Alves ${ }^{2}$ \\ Afonso Machado Grecco ${ }^{3}$
}

\begin{abstract}
Resumo: Neste relato enfatizamos o papel da Música na montagem da obra "Dançar as coisas do pago", projeto de extensão realizado em 2018, na Universidade Federal de Santa Maria. Partimos da utilização de canções como inspirações/perguntas condutoras dos procedimentos de criação. Em torno de 28 artistas com diversos corpos (com e sem deficiências, faixas etárias diversas e experiências distintas em/com Dança) integraram o elenco. Destacamos a importância que a experiência teve na formação dos futuros professores e professoras envolvidas. Também ressaltamos o quanto o repertório musical escolhido trouxe elementos para acessar memórias e 0 imaginário de cada um, favorecendo a criação e sobretudo a expressividade e a autoria dos bailarinos.
\end{abstract}

Palavras-Chave: Música e Dança; Processo de Criação; Inclusão.

\section{MUSIC AS A POETIC INSPIRATION FOR CREATION: REPORTS ON THE SETTING OF "DANÇAR AS COISAS DO PAGO"}

\begin{abstract}
In this report we emphasize the role of Music in the setting up of the work "Dançar as coisas do pago", extension project carried out in 2018, at the Universidade Federal de Santa Maria. We started from the use of songs as inspirations / questions that lead to the creation procedures. On average, 28 artists with different bodies (with and without disabilities, different age groups and different experiences in / with Dance) were part of the cast. We highlight the importance that the experience had in the training of future teachers involved. We also emphasize how much the chosen musical repertoire brought elements to access memories and the imaginary of each one, favoring the creation and above all the expressiveness and authorship of the dancers.
\end{abstract}

\footnotetext{
${ }^{1}$ Artista da Dança e Professora dos Cursos de Dança-Licenciatura e Educação Física-Licenciatura da Universidade Federal de Santa Maria. Doutora e Mestra em Educação pela Universidade Federal de Pelotas. Especialista em Psicopedagogia (UCPel). Pedagoga e Licenciada em Dança pela UFpel.

2 Licenciada em Educação Física (UFSM). Mestra em Pedagogia do Movimento Humano (UGF/RJ) e Doutora em Motricidade Humana (Especialidade em Dança/UTL/PT)

${ }^{3}$ O cantor Pirisca Grecco nasceu em 1971, junto com a Califórnia da Canção Nativa, na Cidade de Uruguaiana, fronteira com Argentina y Uruguai. Professor y aprendiz da ciência da Música, metade da sua vida dedicou-se a fazer arte, contribuindo com o cancioneiro gaúcho através do trabalho autoral. Tem destacada participação nos Festivais de Música y Cinema do Sul do Brasil. Em 8 Álbuns lançados, conquistou 8 prêmio açorianos, incluindo DVD do Ano 2016.
}

BARBOZA, Mônica Corrêa de Borba; ALVES, Mara Rubia; GRECCO, Afonso Machado. A música como inspiração poética para a criação: relatos sobre a montagem do espetáculo "Dançar as coisas do Pago". Revista da FUNDARTE. Montenegro, p.189-214, ano 20, oㅡ 40, janeiro/março de 2020.

Disponível em: http://.seer.fundarte.rs.gov.br/index.php/RevistadaFundarte/index> 31 de março de 2020. 


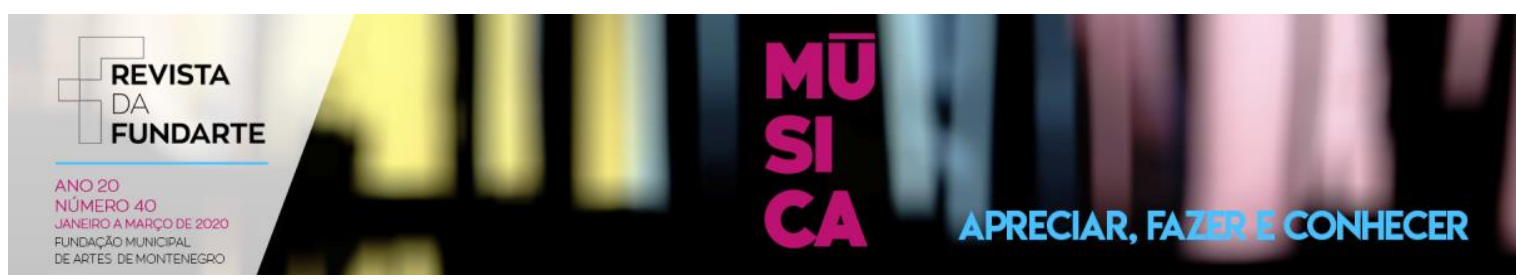

Keywords: Music and Dance; Creation process; Inclusion.

\section{Cevando o mate... considerações iniciais}

Neste relato revivemos sensações e aprendizagens de vida e de Arte que surgiram a partir de um processo de criação desenvolvido durante o ano letivo de 2018. Por meio de um projeto de extensão da Universidade Federal de Santa Maria, propusemos a montagem de uma obra, que culminou na estreia de "Dançar as coisas do pago". Este espetáculo foi resultado de um fazer coletivo e interdisciplinar que extrapolou os muros da instituição e envolveu artistas da Música Gaúcha, docentes da universidade, acadêmicas de diversas áreas e jovens e adultos da comunidade, hoje todos e todas intérpretes-criadores do trabalho.

Dedicamos nossos esforços artísticos e científicos para compartilhar um espetáculo que fosse o mais acessível possível, sobretudo porque tinhamos em nosso elenco bailarinos com diversos corpos, potencialidades e necessidades. Nós que defendemos a premissa que de todos e todas podem dançar, não poderíamos compor um espetáculo de Dança e de Música que não fosse acessível. Assim, além de interpretação de Lingua Brasileira de Sinais, conduzimos a Audiodescrição Simultânea para que o público com deficiência visual também fosse plenamente contemplado.

No presente texto abordaremos com mais ênfase a importância da Música como elemento potencializador do processo de criação das cenas, sobretudo no trabalho com o elenco extremamente plural que participou do processo. Diversas formas de comunicar e expressar o sentir e pertencer a nossa cultura amalgamavam-se assim, trazendo potências únicas às criações.

A questão do uso de uma nomenclatura como "Dança Inclusiva" ou mesmo a identificação de que em nosso elenco havia bailarinos com deficiência, em nosso entendimento é delicada e controversa. Em verdade, enquanto precisarmos nomear ou ressaltar que uma montagem conta ou é protagonizada por artistas com deficiência estamos claramente reiterando que a regra em nossa sociedade é como inspiração poética para a criação: relatos sobre a montagem do espetáculo "Dançar as coisas do Pago". Revista da FUNDARTE. Montenegro, p.189-214, ano 20, no 40, janeiro/março de 2020.

Disponível em: http://seer.fundarte.rs.gov.br/index.php/RevistadaFundarte/index> 31 de março de 2020. 


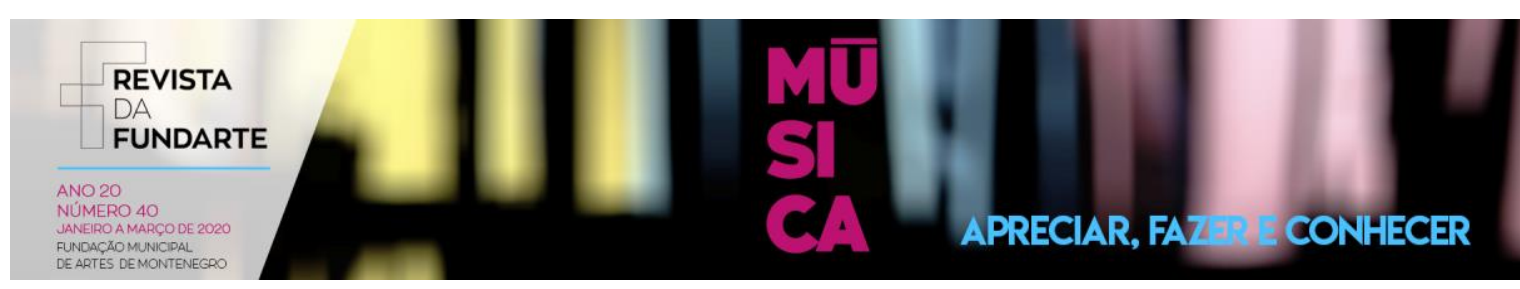

exatamente o oposto. Ou seja, ainda é recorrente nas práticas tradicionais de criação nas Artes Cênicas a ideia de que alguns corpos seriam aptos para estar em cena. Teixeira (2010), muito bem destaca que o uso de terminologias distintas para tratar do corpo e da pessoa com deficiência ao longo da história, "não modificou o olhar social sobre o corpo que segue contentando-se com brechas na sociedade" (p. 38).

Revisitando as reflexões trazidas por Teixeira (2010), militante e artista brasileira com deficiência, também percebemos que muitas vezes, os trabalhos desenvolvidos com coletivos que contemplem artistas com deficiência, via de regra têm reforçando esteriótipos totalmente equivocados e que acabam por reproduzir ideias e frases prontas como a de que seriam "exemplos de vida e de superação" (p. 38). Esta visão coloca a deficiência antes da pessoa, antes do artista, e guarda a premissa de que o corpo com deficiência é incapaz.

Como também aponta muito bem Teixeira (2010), quando está em cena o artista com deficiência pode trazer à tona suas poéticas e estéticas, rompendo com padrões que insistem em operar no imaginário social, tais como "os modelos de perfeição e produtividade física, a supremacia do corpo bípede, da visão bidimensional, da audição perfeita, do raciocícinio rápido e lógico...". Dessa forma, explica a autora, a sociedade em geral tende a uma lógica de "normalização" ou de correção do corpo com deficiência. Um equívoco que pode nos levar a não olhar para sua particularidade como potência.

Mas, diante de todo um contexto, sobretudo no campo da Dança no Brasil, em que ainda são poucos os trabalhos de formação com públicos diversos e para públicos diversos, é necessário, ainda, cremos, que destaquemos a particularidade que envolve elencos como nosso. Desse modo, podemos contribuir para dar visibilidade às potencialidades artísticas de todos e de todas as pessoas e também, avançar do ponto de vista de estratégias de trabalho que superem algumas práticas. Práticas excludentes que ora formam grupos com predominância de

BARBOZA, Mônica Corrêa de Borba; ALVES, Mara Rubia; GRECCO, Afonso Machado. A música como inspiração poética para a criação: relatos sobre a montagem do espetáculo "Dançar as coisas do Pago". Revista da FUNDARTE. Montenegro, p.189-214, ano 20, o 40, janeiro/março de 2020.

Disponível em: http://seer.fundarte.rs.gov.br/index.php/RevistadaFundarte/index> 31 de março de 2020. 


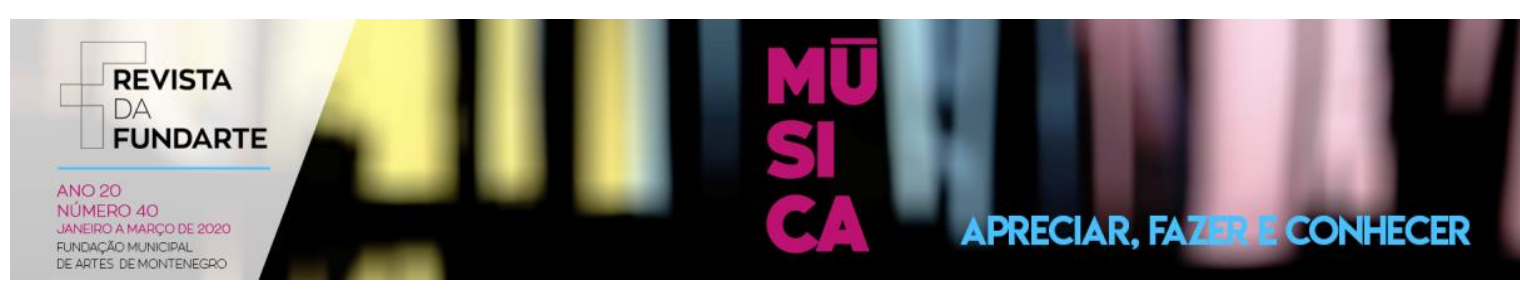

artistas com deficiência criando verdadeiros "guetos artísticos" ${ }^{4}$, ora, sem nenhum artista "diferente" ou fora dos padrões tradicionais reproduzidos nas práticas de Dança profissional.

Assim, nos interessa dizer/propor que sejam grupos ou companhias de dança e ponto. Quando efetivamente tivermos mudado nossos paradigmas e práticas, não serão mais necessárias estas adjetivações ou separações. Daí porque é imprescindível trabalhar novos olhares, mirando para os diferentes homens e mulheres em suas fortalezas e capacidades. Para nós, este foi um espetáculo de Dança e Música, apenas, sem a necessidade de rotulações ou enquadramentos outros.

No trabalho, tinhamos aproximadamente 28 pessoas atuando dentro e fora da cena. Por ser um projeto de extensão de natureza interdisciplinar, havia no grupo acadêmicas dos cursos de Terapia Ocupacional, Dança (Licenciatura e Bacharelado), e Educação Física, além de professores de Música. No elenco que atuava em cena, participavam também algumas pessoas das famílias dos bailarinos que se somaram à proposta. Havia entre elas uma professora da Educação Básica, uma profissional da área da Saúde e outras três mulheres responsáveis pelos cuidados da casa. Assim, a pluralidade de faixas etárias, vivências e corpos estavam ali, como estímulos e "material" para a criação.

Para que seja possível trazer da melhor forma os elementos centrais que ora focamos, este relato está organizado, a seguir, em dois tópicos, acrescidos das condiderações finais. Esta foi a estrutura que nos pareceu mais didática.

\section{Ser gaúcho, ser gaúcha... do trote ao galope, a proposta de criação}

Partimos da premissa de que os artistas, ao compor suas próprias Danças, estariam também falando de si mesmos. Assim, buscávamos a todo momento propor experiências de criação que não os colocassem como meros reprodutores,

\footnotetext{
${ }^{4}$ Expressão utilizada por Teixeira (2010, p. 40).

BARBOZA, Mônica Corrêa de Borba; ALVES, Mara Rubia; GRECCO, Afonso Machado. A música como inspiração poética para a criação: relatos sobre a montagem do espetáculo "Dançar as coisas do Pago". Revista da FUNDARTE. Montenegro, p.189-214, ano 20, o 40, janeiro/março de 2020.

Disponível em: http://.seer.fundarte.rs.gov.br/index.php/RevistadaFundarte/index> 31 de março de 2020.
} 


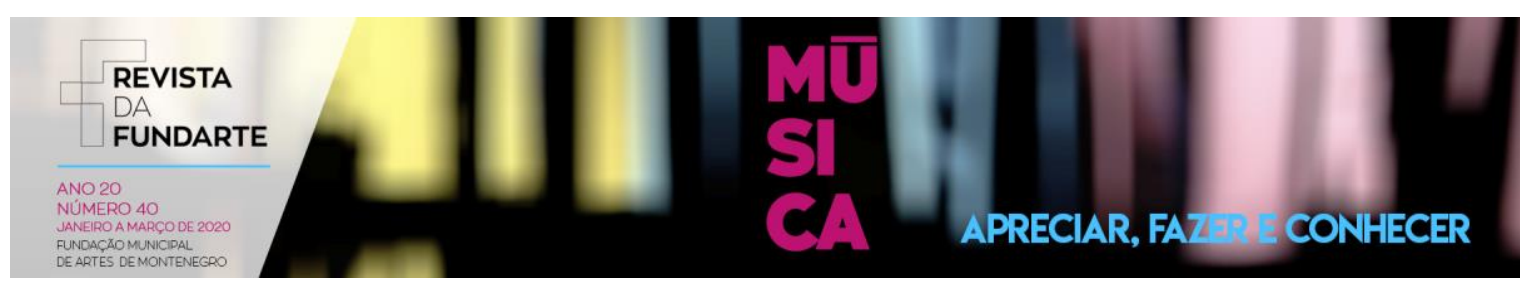

ou mesmo em que estivessem apenas representando a própria deficiência, assim como nos instiga Teixeira (2010), ao fazer suas ponderações. Desejávamos contribuir com a formação artística dos bailarinos e baliarinas e dar vazão a suas capacidades criativas.

Chegamos a temática ou ao ponto de partida para a montagem em torno do que seria ser gaúcho/gaúcha, na leitura daquele coletivo. Isso, porque nos parecia algo muito forte entre os presentes e também porque já era uma questão de alguma forma trabalhada em espetáculos anteriores do grupo. Então, buscamos sublinhar aspectos que em nosso entendimento têm ficado invisibilizados no universo do tradicionalismo gaúcho. No release do espetáculo escrevemos que o trabalho propunha "um olhar que ressignifica padrões historicamente construídos" e nele os artistas expressam e "movimentam seus modos de pertencimento à cultura, a partir dos 'fios que tecem suas vidas'”. Assim como Pina Baush, nos interessava e interessa fortemente, "apresentar experiências humanas ressignificadas esteticamente" (SILVEIRA e MUNIZ, 2013, p. 98), mobiliza-nos trazer à cena, o que move cada um dos bailarinos em suas existências.

A Dança Contemporânea, nos movimenta, "pede por uma nova ontologia que admita 0 devir qualquer da dança por acolher a potência (política) de heterogeneidade que ela comporta" (ROCHA, 2011, p. 129). Como nos ressalta Rocha (2011) "uma ontologia que não poderia ser outra senão uma ontologia da diferença" (p. 129). A Dança Contemporânea, guarda o princípio da pergunta, ou como diria a autora, instiga a diferença, o desajuste, o encontro com a Dança própria de cada bailarino ou bailarina. Assim, este modo de produzir Dança nos trouxe elementos potentes para pensar/construir cada uma das cenas, de forma colaborativa, neste híbrido das criações individuais e coletivas. Como nos convocou Teixeira (2010), buscamos constantemente possibilitar as melhores condições para o protagonismo dos bailarinos e bailarinas fugindo de uma tendência perigosa de que se tornassem "um meio de exibição gratuito" (p. 43), ou como expõe a autora,

BARBOZA, Mônica Corrêa de Borba; ALVES, Mara Rubia; GRECCO, Afonso Machado. A música como inspiração poética para a criação: relatos sobre a montagem do espetáculo "Dançar as coisas do Pago". Revista da FUNDARTE. Montenegro, p.189-214, ano 20, o 40, janeiro/março de 2020.

Disponível em: http://seer.fundarte.rs.gov.br/index.php/RevistadaFundarte/index> 31 de março de 2020. 


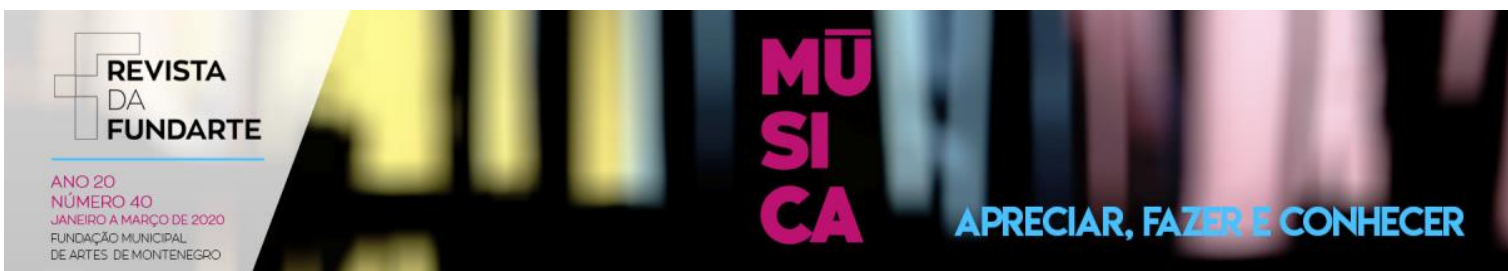

coadjuvantes em obras que simplesmente os "jogassem" ou concedessem espaço para sua inserção em cena.

Inspiramo-nos fortemente no trabalho desenvolvido por Pina Bausch, que, como explica Berté (2015), traz em sua metodologia o princípio de que os bailarinos e bailarnas com os quais cria, sejam convocados a partir de suas "vivências e seus afetos, para serem cocriadores" (p. 55). Como explicam também Silveira e Muniz (2013), o "Metódo das Perguntas e Respostas" desenvolvido e aprimorado por Pina Baush, parte de questões colocadas pela diretora, perguntas que mobilizam os bailarinos e bailarinas a moverem-se, respondendo-as com sequências de movimentos, verbalmente ou com gestos do cotidiano, mobilizando assim, as criações. "Pina incentivava cada bailarino a se posicionar individualmente, a obter seus próprios pensamentos, sentimentos, associações" (SILVEIRA e MUNIZ, 2013, p. 100) e da mesma forma, objetivávamos que vida e Arte se entrelaçassem na obra, por meio das respostas trazidas pelos bailarinos e bailarinas.

Em um primeiro momento, alguns acontecimentos e/ou situações muito peculiares vivenciadas com o grupo se misturavam com a proposta, fazendo vir, por meio dos bailarinos, músicos e diretoras, canções, metáforas, analogias, inspirações sonoras que foram utilizadas na composição das cenas. Mais do que isso, foram mobilizadoras das perguntas que movimentaram as criações. Neste aspecto, trabalhamos de modo distinto ao que trabalhava a maior parte das vezes Pina Bausch. A artista, primeiro elaborava e compunha as cenas, para só depois selecionar a sonoridade que a comporia, como explicam Silveira e Muniz (2013). Em nosso caso, a música foi muitas vezes a própria pergunta, como veremos a seguir.

\section{Para criar, ouvir os nossos cancioneiros...}

"Negrinho do pastoreio, acendo esta vela pra ti e peço que me devolvas, a querência que eu perdi...". Ouvia-se o dedilhar suave do violão e a voz de um cantarolar pela sala de Dança. Era a poesia de Barbosa Lessa na melodia de "Negrinho do Pastoreio" que dava fundo ao trabalho de umas quinze pessoas BARBOZA, Mônica Corrêa de Borba; ALVES, Mara Rubia; GRECCO, Afonso Machado. A música como inspiração poética para a criação: relatos sobre a montagem do espetáculo "Dançar as coisas do Pago". Revista da FUNDARTE. Montenegro, p.189-214, ano 20, oㅡ 40, janeiro/março de 2020.

Disponível em: http://.seer.fundarte.rs.gov.br/index.php/RevistadaFundarte/index> 31 de março de 2020. 


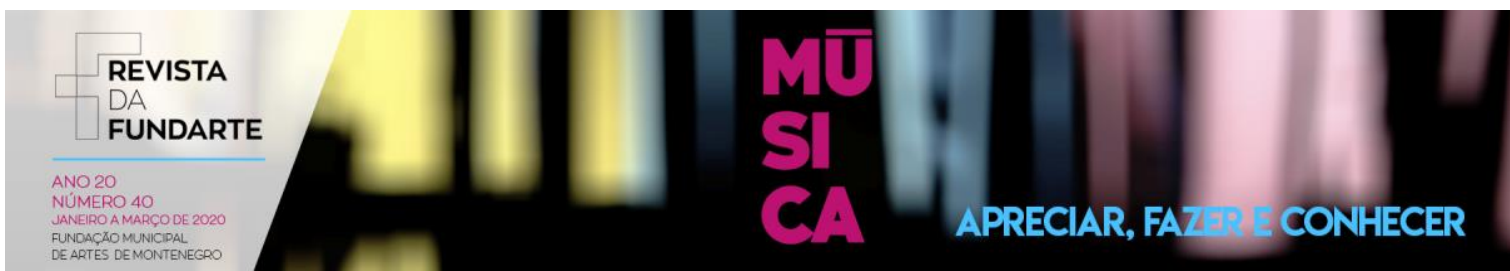

espalhadas em pequenos grupos pela sala em que realizavam experimentos de movimentos.

"Negrinho do pastoreio, traz a mim o meu rincão, eu te acendo esta velinha, nela está meu coração...", das notas suaves vai emergindo a força daquela canção que aos poucos deixa de ser o fundo, para ser o centro. Ouve-se uma voz feminina que cantarola junto... Uma atmosfera diferente se instaura... De repente, uma das bailarinas que trabalha e experimenta movimentos com um lenço nas mãos chora... Lágrimas rolam dos olhos da menina com espectro autista que pouco consegue dizer o que sente, mas expressa sua emoção. No abraço com a professora, ela diz que não está triste... Seu corpo expressa e dá sinais de que aquela poesia a afetou.

Assim começamos a narrar como se desenvolveram os procedimentos de criação para a composição das cenas com este breve relato, que tornou-se um dos registros mais bonitos que guardamos na memória. Em um primeiro momento, imaginávamos, por nossa própria experiência como artistas, o quanto a Música poderia ser instigante para as criações, mas não tinhamos a exata dimensão do quanto ela seria definidora no trabalho que desenvolveríamos.

Em contato com a experiência compartilhada por Vieira e Avelino (2014), encontramos algumas reflexões bastante instigantes que muito se relacionam com nosso trabalho e proposta. As pesquisadoras trazem apontamentos em torno de uma investigação que centrou-se em explorar as interfaces entre as áreas da Dança e da Música em processos de criação. Como explanam as artistas, é bastante comum no campo da Dança a utilização de procedimentos de criação, a partir de elementos musicais para impulsionar a expressividade dos bailarinos e bailarinas. As pesquisadoras destacam por exemplo, o uso de instrumentos musiciais específicos ou canções para "exploração dos contrastes entre o tempo da música e o corpo do intérprete" (p.136). E então salientam que os bailarinos podem ou não estar atentos a estes elementos, dependendo da condução dos procedimentos de criação. As estudiosas também citam trabalhos como os dirigidos por Paulo Pederneiras no Grupo Corpo, cujas obras tem esta relação muito forte com a BARBOZA, Mônica Corrêa de Borba; ALVES, Mara Rubia; GRECCO, Afonso Machado. A música como inspiração poética para a criação: relatos sobre a montagem do espetáculo "Dançar as coisas do Pago". Revista da FUNDARTE. Montenegro, p.189-214, ano 20, ํㅡ 40, janeiro/março de 2020.

Disponível em: http://.seer.fundarte.rs.gov.br/index.php/RevistadaFundarte/index> 31 de março de 2020. 


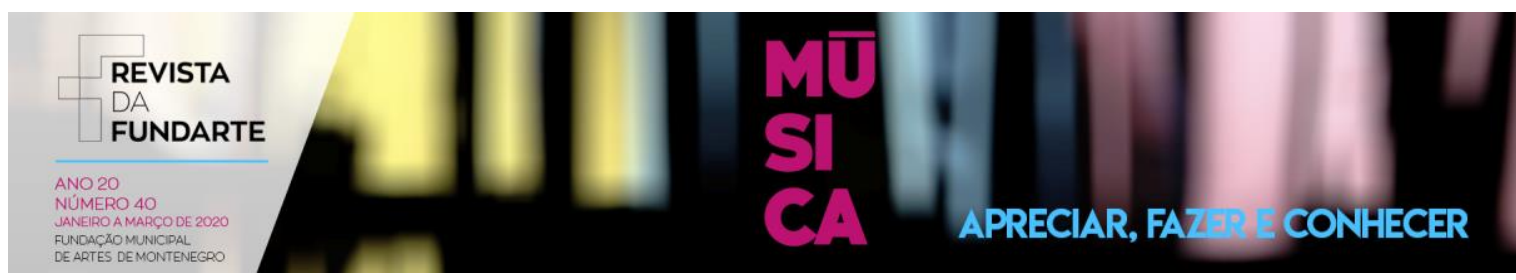

Música, desde o processo de composição. Ressaltam ainda, diferentes perspectivas por elas experimentadas, com intuito de investigar as relações entre Música e Dança em processos criativos.

Em nosso caso, em um primeiro momento, antes da presença do músico nos ensaios, trabalhavámos com som mecânico, a partir de canções de inspiração, selecionadas dentro de repertórios da Música Gaúcha e canções que se aproximavam dos temas que seriam trabalhados nas cenas.

Como afirmamos, algumas cenas foram trazidas para a obra após um incidente ou vivência específica do grupo, como por exemplo, em "Os amores e paixões", onde abordamos diversas formas de relacionamentos, contrapondo-nos a uma visão heteronormativa muito reproduzida nos ambientes das Danças Gaúchas. Começamos a trabalhar com o tema, a partir de uma prática de um dos bailarinos que, encantado com uma moça, todos encontros contava sua ida a uma loja de alianças e simulava a entrada no cerimonial do casamento. Só conseguíamos iniciar os trabalhos daquele dia ou ensaio, depois deste ritual, então, ele entrou no espetáculo nesta cena de casais. Assim, interessávamos no que "o movia" naquele momento de sua vida.

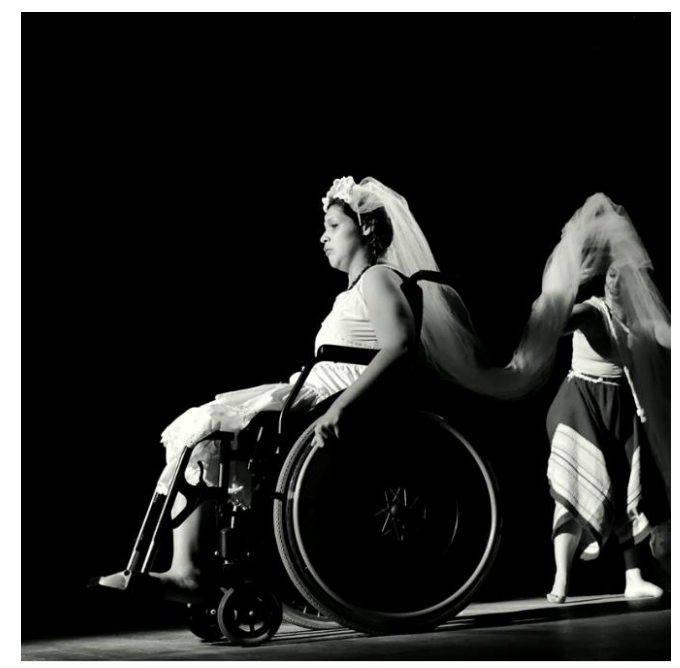

Figura 1: Inspiração no casamento

Créditos da imagem: Dartanhan Baldez

BARBOZA, Mônica Corrêa figueiredo como inspiração poética para a criação: relatos sobre a montagem do espetáculo "Dançar as coisas do Pago". Revista da FUNDARTE. Montenegro, p.189-214, ano 20, no 40, janeiro/março de 2020.

Disponível em: http://seer.fundarte.rs.gov.br/index.php/RevistadaFundarte/index> 31 de março de 2020. 


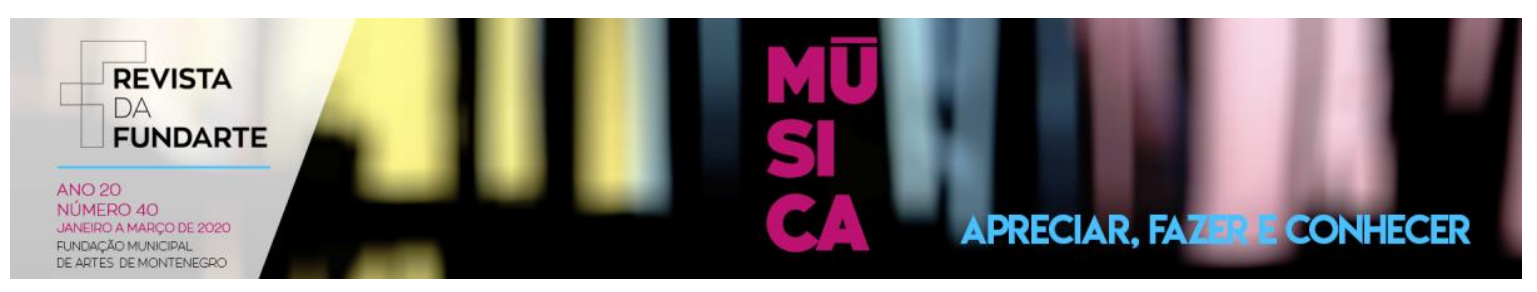

Muitas vezes, a seleção musical inicial estava centrada em sua sonoridade, na atmosfera que aquela música propiciava, como é o caso da cena "Invernos cotidianos: abraço é calor, indiferença é gelado", onde trabalhamos a canção "Estrela, estrela" de Vitor Ramil. No período de junho e julho, chegávamos para as aulas e ensaios todos com os corpos enrijecidos e com bastante desconforto com as temperaturas baixas do período. Então, a partir desta sensação discutimos a condição de vida dos bailarinos e aquilo que mais os agradava fazer nestes momentos. Logo, contrastamos estas percepções e possibilidades com a vida das pessoas em situação de rua, trazendo perguntas sobre como seria esta sensação. Aquela sutileza poética e a sonoridade da canção de Ramil, em nosso ver, trazia para as respostas de movimento, um lugar de instrospecção e até "lentidão", que favorecia naquele momento a dramaturgia que buscávamos. Assim, os bailarinos e bailarinas começavam a experimentar abraços e afastamentos, aquecer e gelar, encontros e desencontros... outros estados corporais entre os seus invernos e daqueles que estão na solidão das ruas.

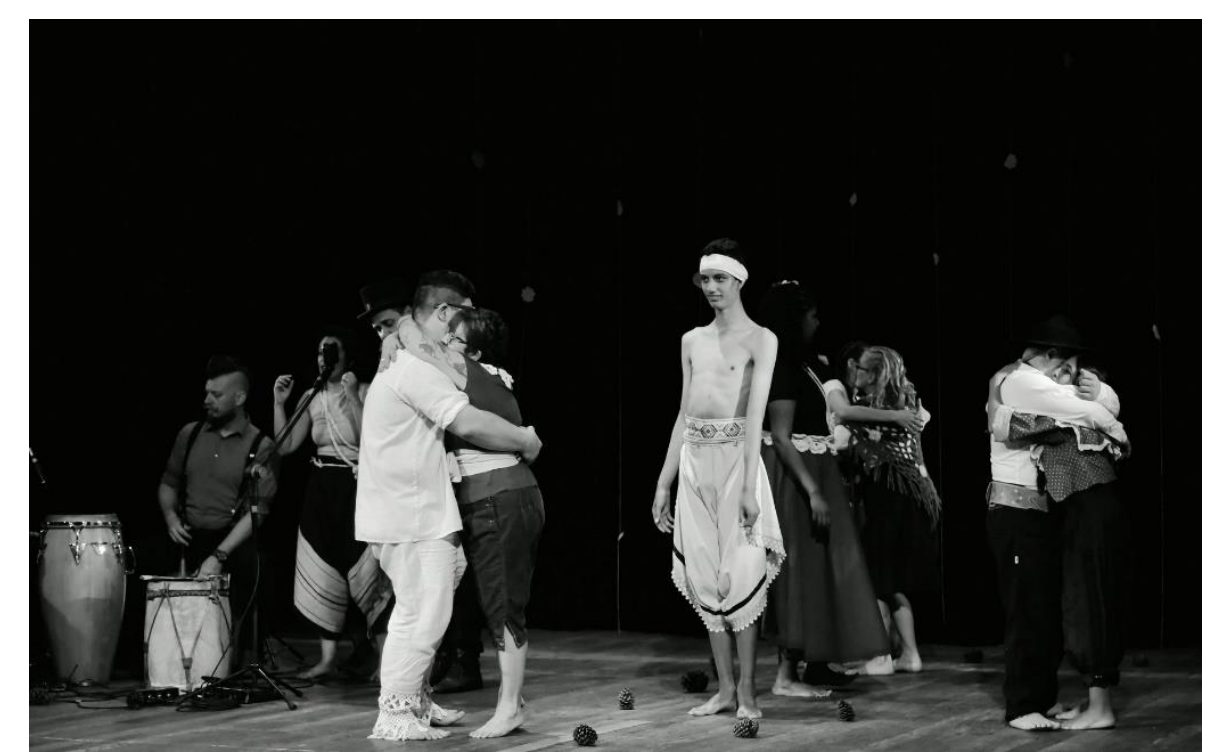

Figura 2: Cena "Invernos cotidianos"

Créditos da imagem: Joan Felipe Michel

BARBOZA, Mônica Corrêa de Borba; ALVES, Mara Rubia; GRECCO, Afonso Machado. A música como inspiração poética para a criação: relatos sobre a montagem do espetáculo "Dançar as coisas do Pago". Revista da FUNDARTE. Montenegro, p.189-214, ano 20, no 40, janeiro/março de 2020.

Disponível em: http://seer.fundarte.rs.gov.br/index.php/RevistadaFundarte/index> 31 de março de 2020. 


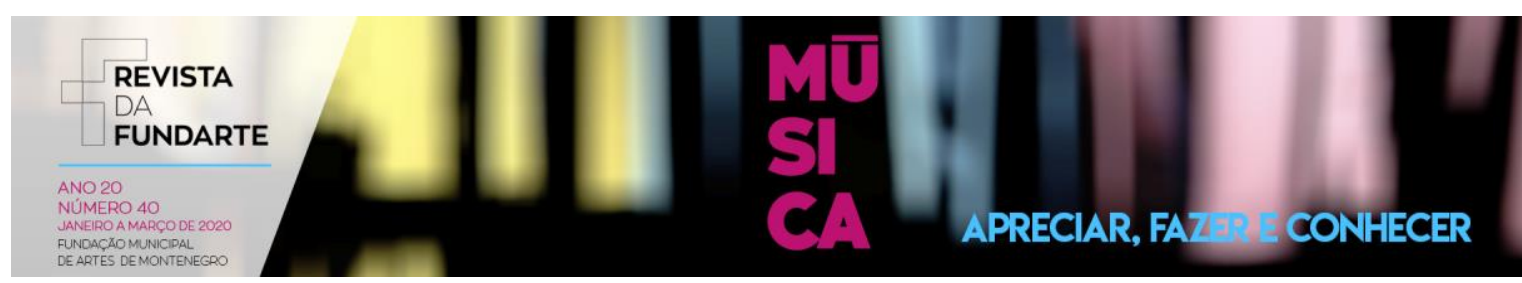

Então, quando a Música opera como pergunta, ela ocupa um outro lugar, diferente de práticas mais convencionais como por exemplo, de buscar-se mover-se metricamente no seu pulso, ou marcação específica. ELA era também a cena, muitas vezes compondo-a ao lado da Dança, em sobreposição ou em alguns momentos nesta interface. Vieira e Avelino (2014), ao abordar o trabalho de Pina Baush, lembram que nas escolhas finais, a diretora trazia de sua intuição, sonoridades que contribuiriam para "compor as difentes atmosferas das cenas" ( $p$. 145). Em nosso caso, essas escolhas aconteciam já no momento de provocação inicial. Essas músicas utilizadas como perguntas iniciais, muitas vezes, também eram misturadas a outras, ou a repertórios trazidos pelos bailarinos e bailarinas.

A presença do chimarrão antes, depois, ou até durante os ensaios, fosse entre os familiares, fosse entre os bailarinos, também foi um impulso criativo. $O$ cevar e preparar o mate, motivou histórias e movimentações que compuseram a cena inicial do espetáculo. Assim, com inspiração da canção "Chimarrão", de Vitor Ramil, podíamos falar do quanto o mate agrega, do que significa no cotidiano daqueles bailarinos, de quais memórias ele evoca. De muitas dessas respostas que vinham muitas vezes oralmente, em um primeiro momento, vinham as falas e frases utilizadas nas cenas e ditas pelos bailarinos. Nesse caso, a letra da música foi fundamental para nosso diálogo e criação. Como salientou Passos (2015), canções com letras podem trazer, em suas palavras e gestos, sentidos que constróem significados e portanto, contribuir com a criação.

BARBOZA, Mônica Corrêa de Borba; ALVES, Mara Rubia; GRECCO, Afonso Machado. A música como inspiração poética para a criação: relatos sobre a montagem do espetáculo "Dançar as coisas do Pago". Revista da FUNDARTE. Montenegro, p.189-214, ano 20, o 40, janeiro/março de 2020.

Disponível em: http://seer.fundarte.rs.gov.br/index.php/RevistadaFundarte/index> 31 de março de 2020. 

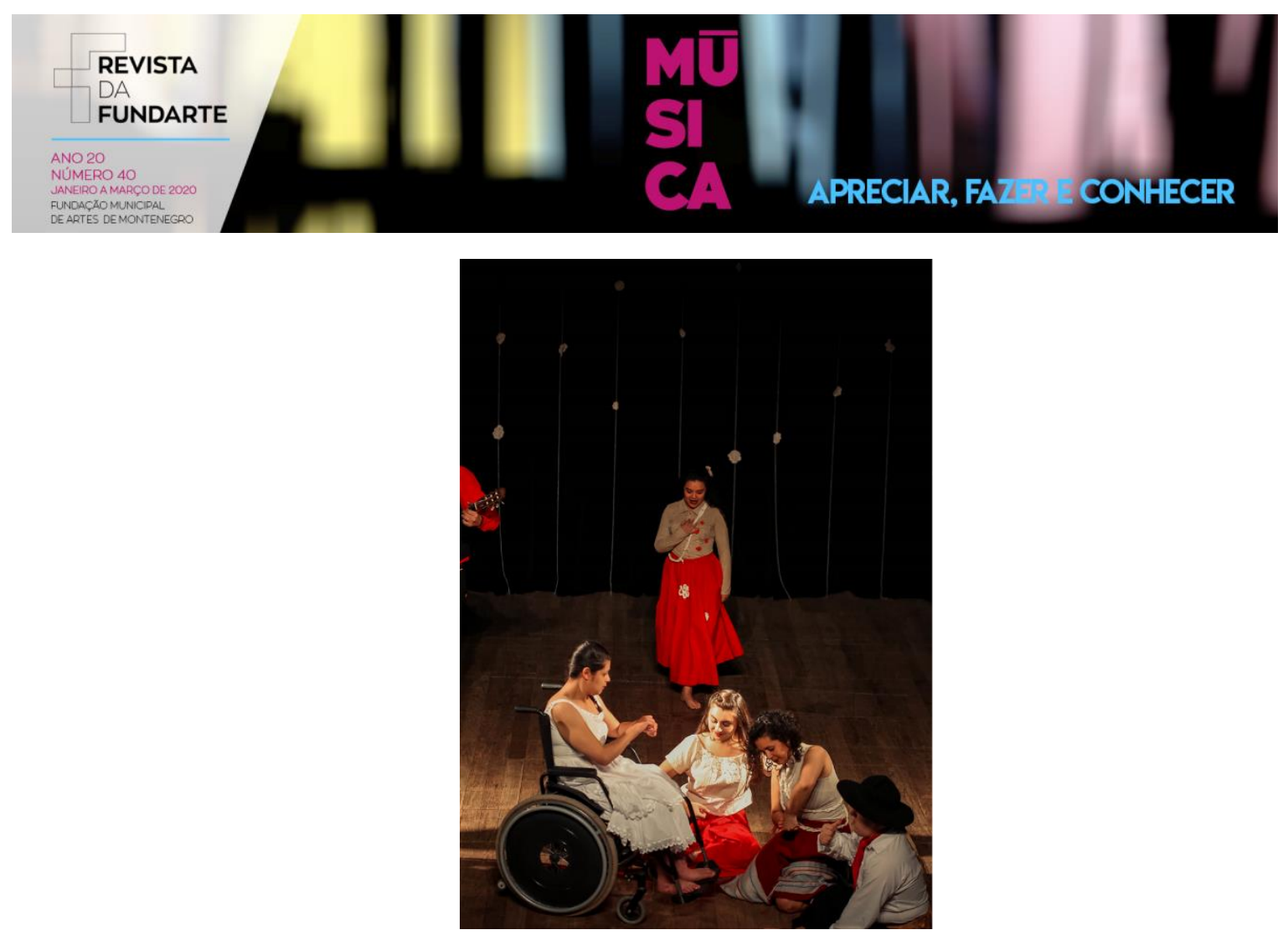

Figura 3: Cena "Roda de Mate"

Créditos da imagem: Joan Felipe Michel

Apesar das Músicas Tradicionais Gaúchas estarem bastante presentes no cotidiano dos bailarinos e bailarinas, nas histórias vividas com seus avós e pais, segundo seus relatos, muitas das canções selecionadas para o processo de criação eram desconhecidas dos bailarinos, pois não necessariamente, eram ouvidas ou dançadas nos Centros de Tradição Gaúcha. Nossa escolha intencional por artistas como Pirisca Grecco, Giba Giba ou Vitor Ramil, trazia, também, essa relação com outras canções, também gaúchas, e não menos sobre o ser gaúcho e gaúcha.

Vários dos bailarinos traziam com frequência pedidos para que colocássemos e dançássemos algumas músicas dos repertórios mais populares do funk carioca. Gostavam do rítmo, traziam coreografias, evocavam por este espaço. A partir disso, pensamos juntos em trazer estes elementos para o espetáculo, em uma cena em que pudéssemos romper com uma lógica do gauchismo somente com a bombacha e as danças e canções do tradicionalismo. Então, "Peleia" do grupo Ultramen, trouxe o rítmo, a ambiência e a reflexão que impulsionou nossas conversas nesse momento como inspiração poética para a criação: relatos sobre a montagem do espetáculo "Dançar as coisas do Pago". Revista da FUNDARTE. Montenegro, p.189-214, ano 20, no 40, janeiro/março de 2020.

Disponível em: http://seer.fundarte.rs.gov.br/index.php/RevistadaFundarte/index> 31 de março de 2020. 


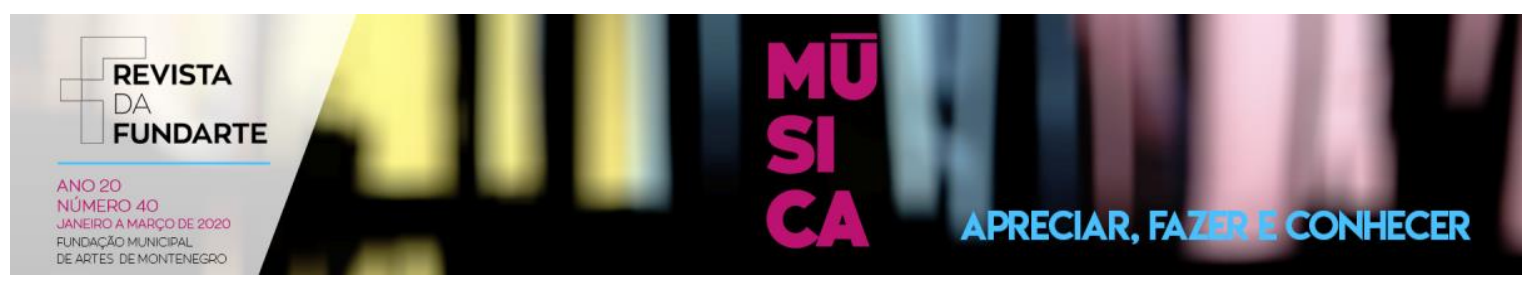

da cena "Outros (nossos) gauchismos". Nesse momento, um dos bailarinos quis "brincar" com o figurino usando boné e bombacha.

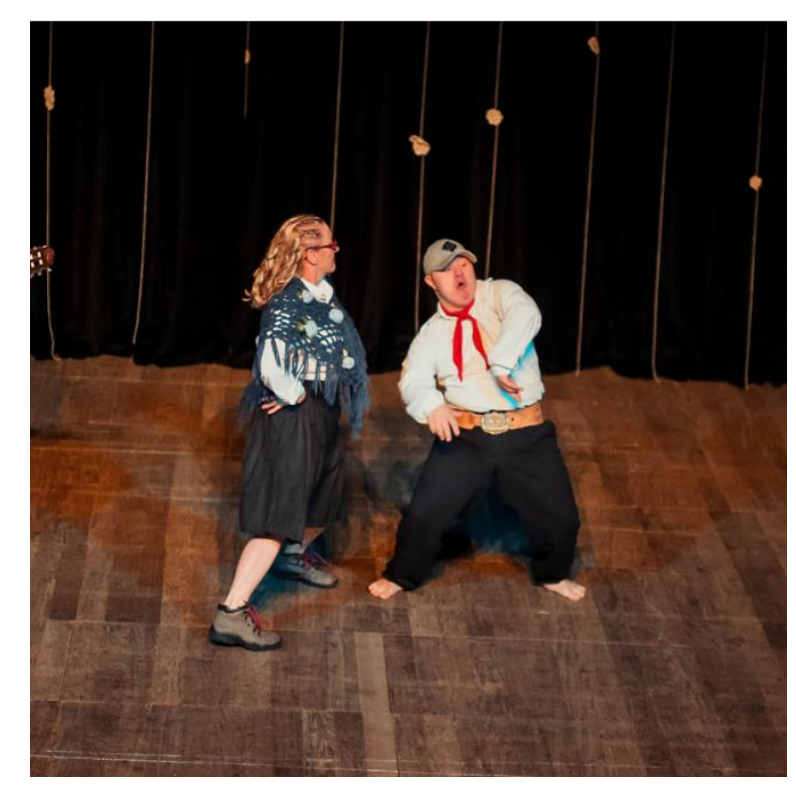

Figura 4: Bailarinos em "Outros (nossos) gauchismos

Créditos da imagem: Joan Felipe Michel

Alguns de nossos bailarinos faziam ou já haviam feito Ecoterapia, e havia uma relação deles muito próxima com cavalos, o que também é sempre muito presente no imaginário gaúcho. Assim, com a canção "Prenda Minha", interpretada por Renato Borguetti, vivenciamos com o rítmo de sua interpretação na gaita, os diferentes pulsos do galope e do trote, no andar a cavalo. Enquanto trabalhávamos em duplas ou trios, nos veio a imagem de carroças, lembramos da "cancha reta", e de repente, uma cadeira de rodas se transformava em um cavalo... A canção naqueles momentos conduzia os rítmos corporais e as sensações na relação do corpo com o cavalo.

BARBOZA, Mônica Corrêa de Borba; ALVES, Mara Rubia; GRECCO, Afonso Machado. A música como inspiração poética para a criação: relatos sobre a montagem do espetáculo "Dançar as coisas do Pago". Revista da FUNDARTE. Montenegro, p.189-214, ano 20, no 40, janeiro/março de 2020.

Disponível em: http://seer.fundarte.rs.gov.br/index.php/RevistadaFundarte/index> 31 de março de 2020. 

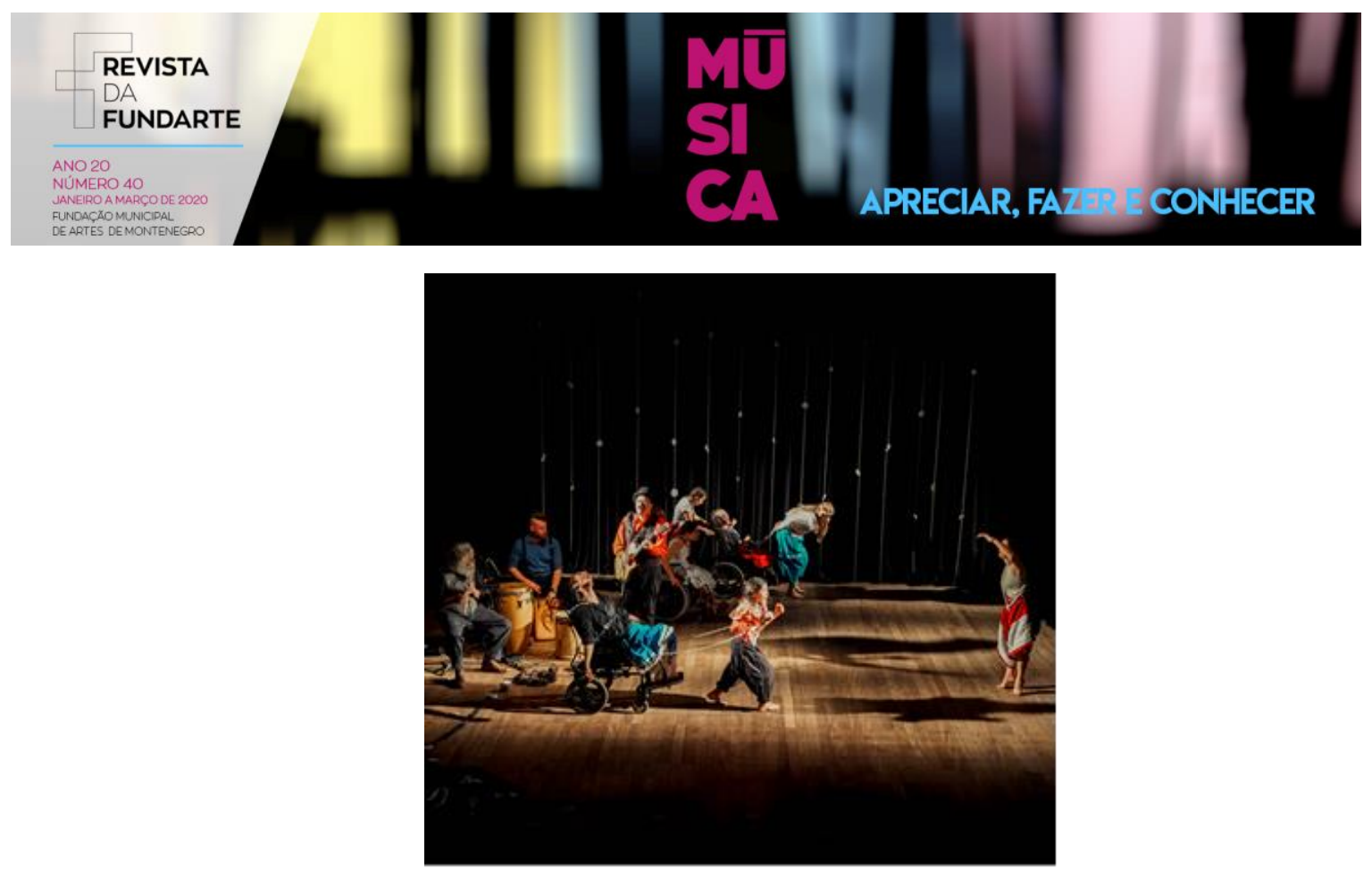

Figura 5: Cena "Cavalgando pela vida"

Créditos da imagem: Joan Felipe Michel

Enquanto propúnhamos as inspirações musiciais, percebíamos por exemplo, por olhares e reações corporais, como um dos bailarinos mais antigos no grupo, que não verbalizava, sentia e reagia àquelas canções. Assim, o artista com paralisia, podia trazer sua Dança. Em par, com uma das professoras, ele conduzia as movimentações que ela espelhava, dessa forma, coreografando-a ou dirigindo-a, a partir dos movimentos que trazia. A todo momento tínhamos conosco a provocação trazida por Teixeira (2010) quando enfatiza:

Trata-se de referendar o trabalho desse artista e enfatizar uma formação de qualidade, que não vitime, cenicamente, o corpo já vitimado e subestimado socialmente, e que reconheça a participação efetiva deste profissional nos processos de trabalho-criação. As dificuldades, visíveis ou não, ecoam nos corpos (em todos os corpos) e, quando desafiadas, assumem uma ação única (TEIXEIRA, 2010, p. 41).

Com este bailaino em especial, mas não somente com ele, trazíamos a todo instante a busca por encontrar modos de nos comunicar, ao encotro de uma escuta sensível à sua Dança, as suas respostas, mas também as suas perguntas de movimento. Assim, ao perceber, a partir do não dito "convecionalmente", mas BARBOZA, Mônica Corrêa de Borba; ALVES, Mara Rubia; GRECCO, Afonso Machado. A música como inspiração poética para a criação: relatos sobre a montagem do espetáculo "Dançar as coisas do Pago". Revista da FUNDARTE. Montenegro, p.189-214, ano 20, no 40, janeiro/março de 2020.

Disponível em: http://seer.fundarte.rs.gov.br/index.php/RevistadaFundarte/index> 31 de março de 2020. 


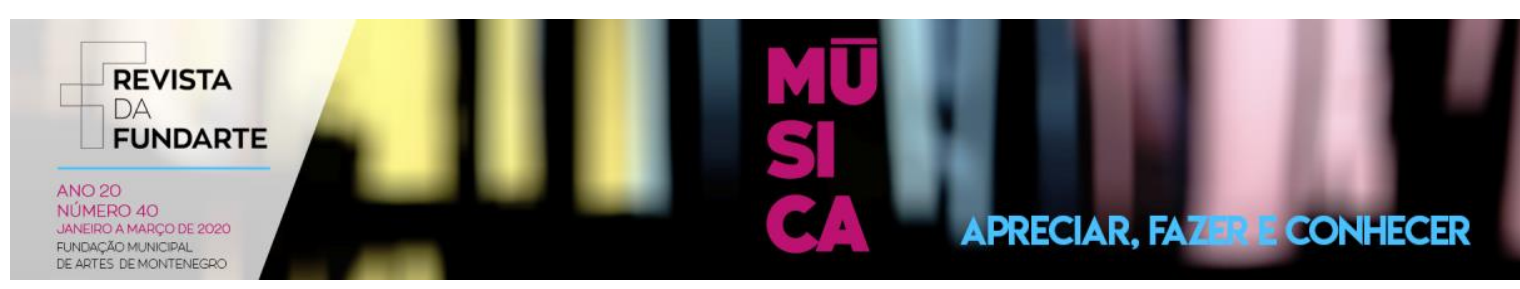

inscrito e expresso pelo corpo, acompanhávamos os modos como o artista retornava às sonoridades e rítmos trazidos nas canções e aos nossos questionamentos verbais. "Como tu queres que eu dance esta alegria, ou esta saudade, ou este frio? Como estes dedos podem expressar este corpo todo? Assim, ele dirigia e conduzia os movimentos e ao mesmo tempo os respondia. Como afirmava Berté (2015), ao abordar a metodologia das perguntas de Pina Baush. "São trechos de vida, experiências, imagens, ideias, ações vividas, imaginadas, e evocadas através de interpelações, perguntas" (p. 59) e nós diríamos, expressas a partir dos olhos, dos poros, das capacidades e das peculiridades de cada um.

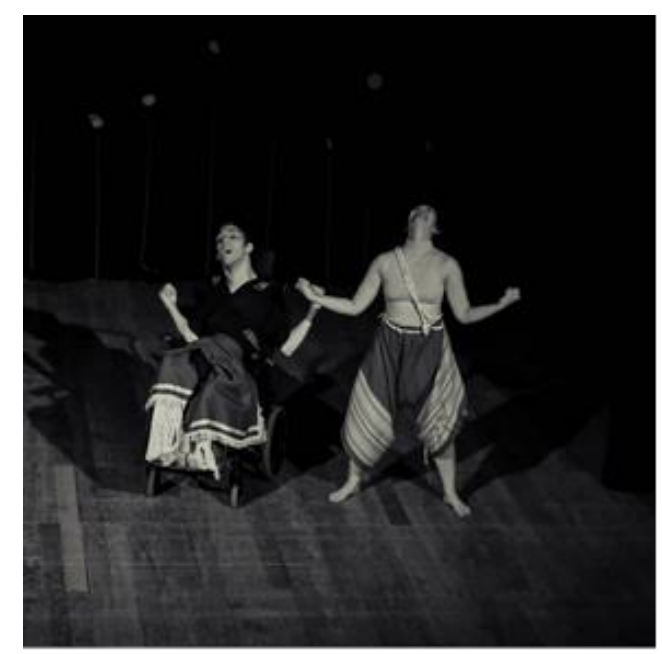

Figura 6: Bailarinos em Duo

Créditos da imagem: Dartanhan Baldez Figueiredo

As perguntas vinham em forma de Música, como afirmamos. Muitas vezes, ela estava presente como ambientação de uma sonoridade relacionada à atmosfera daquele momento do espetáculo, ou mesmo porque trazia na sua poética elementos para compor a dramaturgia. A Música, a maior parte das vezes suscitou emoções e estados corporais. Assim, por exemplo, quando estávamos trabalhando a cena "A força da mulher", onde retratávamos o protagonismo feminino na vida dos integrantes e familiares do grupo, trabalhamos com a canção "Querência",

BARBOZA, Mônica Corrêa de Borba; ALVES, Mara Rubia; GRECCO, Afonso Machado. A música como inspiração poética para a criação: relatos sobre a montagem do espetáculo "Dançar as coisas do Pago". Revista da FUNDARTE. Montenegro, p.189-214, ano 20, o 40, janeiro/março de 2020.

Disponível em: http://seer.fundarte.rs.gov.br/index.php/RevistadaFundarte/index> 31 de março de 2020. 


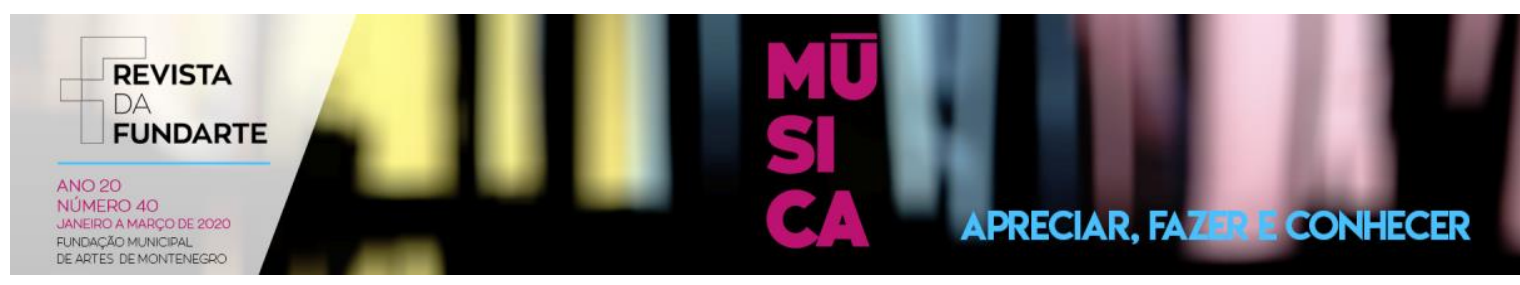

interpretada por Vitor Ramil. Ao ouvir a poesia que tratava de partidas e idas e vindas, começamos a conversar sobre a canção, transformando memórias de mulheres em movimentos. Discutimos a opressão e a sobrecarga a que são acometidas as mulheres, e fomos aos poucos "colecionando" movimentos. Ao final, o papel da direção artística era compor e realizar rearranjos, a partir do material e das respostas trazidas pelas bailarinas. No elenco desta cena, as mulheres que tradicionalmente vinham até a universidade para trazer seus filhos estavam, pela primeira vez na cena, dançando seus afetos e histórias.

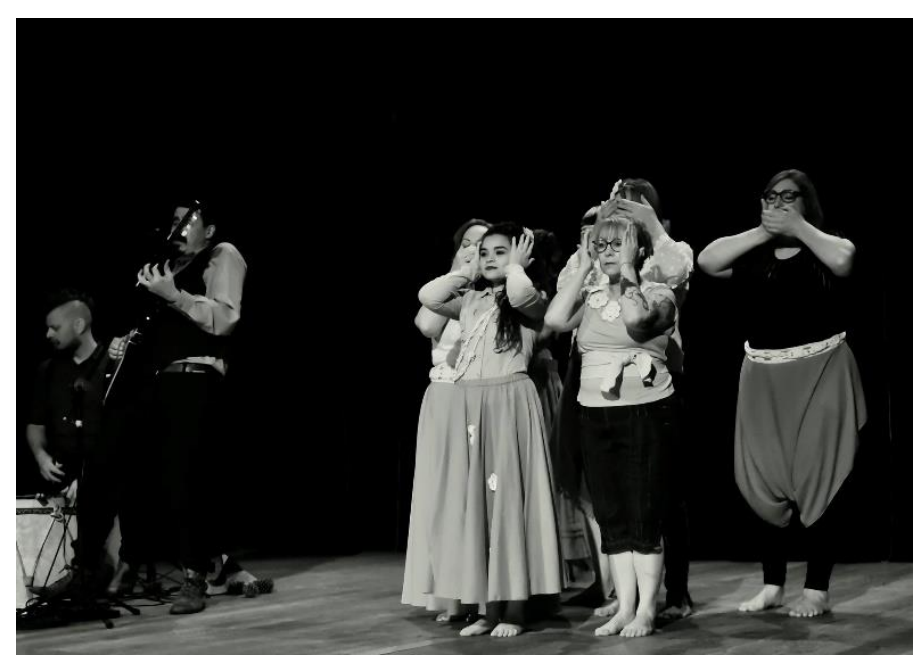

Figura 7: Cena "A força da mulher"

Créditos da imagem: Dartanhan Baldez Figueiredo

$\mathrm{Na}$ maior parte das cenas, os bailarinos trabalhavam a partir das perguntas/estímulos e músicas, em pequenos grupos, por escolha espontânea daquele dia em específico, ou por vezes, a partir de uma proposição das direitoras. Por exemplo, quanto experimentávamos formas de criar, cavaleiros e cavalos, nos distiruímos em duplas organziadas pelas professoras. Após os experimentos, normalmente, os agrupamentos ou duplas mostravam para o grupo suas criações. Ao apreciá-las, podíamos ir selecionando e excluindo coisas que eram reagrupadas pelas direitoras.

Para criar a cena "Lanceiras Negras do Século XXl", partimos da canção BARBOZA, Mônica Corrêa de Borba; ALVES, Mara Rubia; GRECCO, Afonso Machado. A música como inspiração poética para a criação: relatos sobre a montagem do espetáculo "Dançar as coisas do Pago". Revista da FUNDARTE. Montenegro, p. 189-214, ano 20, ํㅡ 40, janeiro/março de 2020.

Disponível em: http://seer.fundarte.rs.gov.br/index.php/RevistadaFundarte/index $>31$ de março de 2020. 


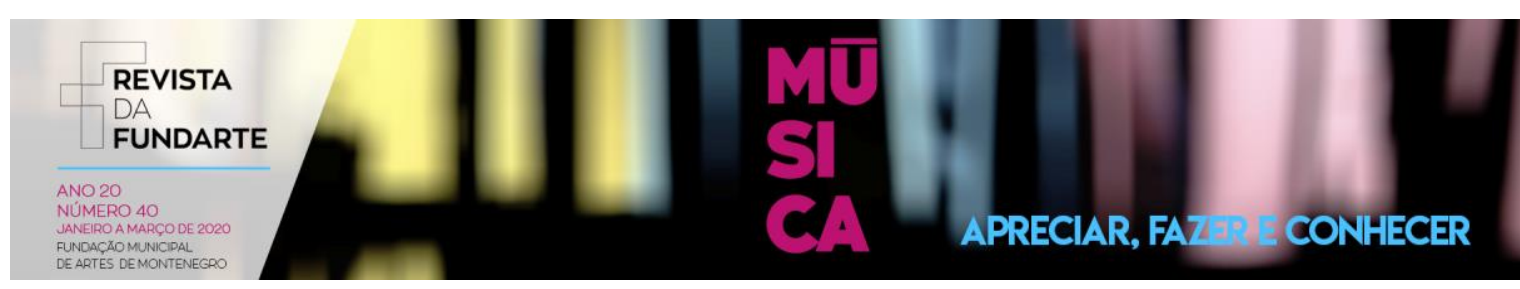

"Outro Um" do artista Giba Giba, canção que trazia a africanidade com força desde seus instrumentos e vocais. Ali, encontrávamos uma atmosfera instigante para pensar e expressar nossa negritude gaúcha, para gritar e expressar "Basta de genocídio ao povo negro!" ou "Porongos, só na cuia do mate!". "Quando se destaca algo de seu contexto original e se coloca em outro contexto, força-se uma observação distanciada deste" (SILVEIRA e MUNIZ, 2013, p. 104), assim, os racismos diários enfrentados pelas artistas e a invisibilidade da contribuição mão negra na cultura gaúcha, ficavam evidentes nos movimentos e dizeres das bailarinas negras que compunham a cena. Como afirmava a própria Pina Baush (2000, p. 12), "quando se traz algo para dentro do teatro algo que em geral se encontra fora, faz apelo ao olhar". Apelavámos àqueles olhares, que sentissem, que se movem-se por meio das cenas. Na versão final da cena, trabalhamos com canção "Mandinga" de Pirisca Grecco.

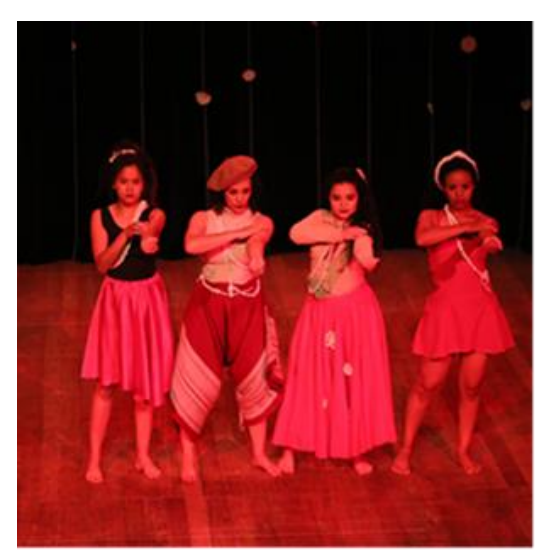

Figura 8: Cena Lanceiras Negras do Século XXI

Conforme os Créditos da imagem: Joan Felipe Michel

avançavam, o direitor musical do espetáculo e artista que estaria conosco no palco, compondo a cena, começou a frequentar os ensaios e conhecer mais de perto o elenco e o material que tínhamos trabalhado. Com sua presença semanal trazia, junto com o mate e o violão, a escuta sensível, ia conhecendo o repertório musical de nossas perguntas e também ia, aos poucos, selecionando algumas canções que poderiam compor cada uma das cenas, na versão final. $O$ fato de o artista estar BARBOZA, Mônica Corrêa de Borba; ALVES, Mara Rubia; GRECCO, Afonso Machado. A música como inspiração poética para a criação: relatos sobre a montagem do espetáculo "Dançar as coisas do Pago". Revista da FUNDARTE. Montenegro, p.189-214, ano 20, no 40, janeiro/março de 2020.

Disponível em: http://seer.fundarte.rs.gov.br/index.php/RevistadaFundarte/index> 31 de março de 2020. 


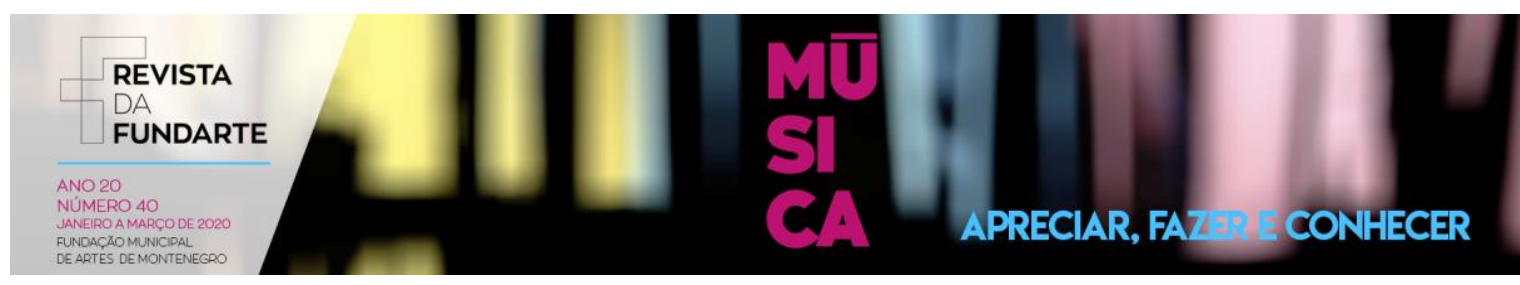

presente nos ensaios, conhecendo os procedimentos de criação e compreendendo como as cenas eram elaboradas foi extremamente enriquecedor, sobretudo, porque podia se aproximar de modos de dançar muito distintos das tradicionais Danças Gaúchas. Em vários momentos nós propúnhamos rítmos ou nuances musicais para o compositor, em outras, ele nos trazia elementos e inspirações, a partir de canções de seu repertório. Assim aconteceu na cena que tratávamos dos "Amores e Paixões", quando a música "Zambita Nueva", de Pirisca Grecco, foi potente nas criações desenvolvidas pelos casais, um deles trazendo da tradicional "Chacarera", elementos para uma nova roupagem em forma de Zamba. A respeito, Vieira e Avelino (2014) muito bem colocam que tanto a Música quanto a Dança, podem influenciar uma à outra, quando feitas ao vivo, na cena. E explicam, "numa coreografia, quando se dá a união, a junção, o entremeio do corpo e som, movimento e melodia, este momento pode se tornar o êxtase, o ponto 'chave' da dança" (p. 140).

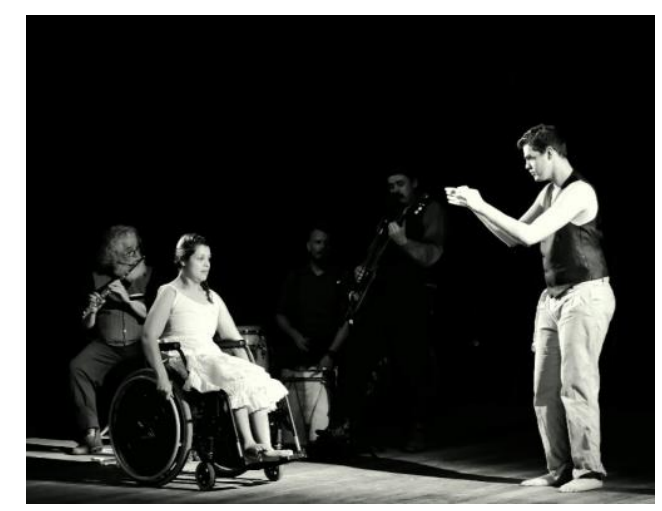

Figura 9: Cena inspirada na Chacarera

Créditos da imagem: Dartanhan Baldez Figueredo

BARBOZA, Mônica Corrêa de Borba; ALVES, Mara Rubia; GRECCO, Afonso Machado. A música como inspiração poética para a criação: relatos sobre a montagem do espetáculo "Dançar as coisas do Pago". Revista da FUNDARTE. Montenegro, p.189-214, ano 20, no 40, janeiro/março de 2020.

Disponível em: http://seer.fundarte.rs.gov.br/index.php/RevistadaFundarte/index> 31 de março de 2020. 

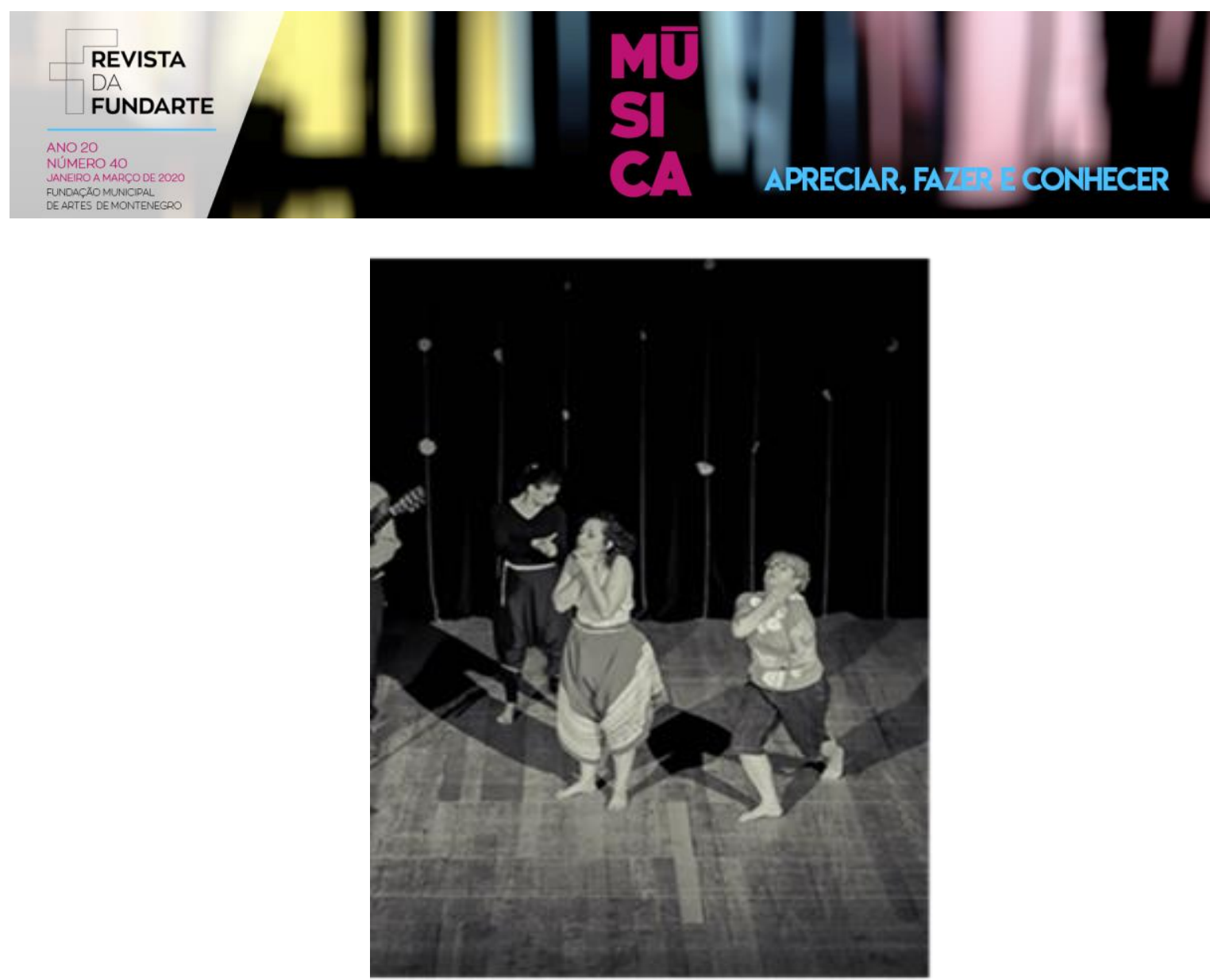

Figura 10: Manifesto Líquido

Créditos da imagem: Joan Felipe Michel

Porém, como também colocam as autoras (VIEIRA e AVELINO, 2014), nem toda a cena de Dança exige uma Música ou sonoridade, podendo o próprio silêncio estar presente nas criações. Outras vezes, podemos utilizar exatamente a pulsação da música para conduzir as movimentaçõs, ou mesmo, construir "dissonâncias" com ela. Em vários momentos letras de músicas foram transformadas em textos interpretados pelos bailarinos, sem acompanhamento musical, como por exemplo quando utilizamos "Manifesto Líquido" de Clarissa Ferreira, como texto/som coreografado, escrito pelo corpo. Também houve cenas em que a canção estava dando-nos a "moldura cênica", como em "Cavalgando pela vida", quando a cancha reta acontecia no palco, ao som de Prenda Minha, revisitada pelos ${ }^{5}$ músicos do espetáculo.

\footnotetext{
${ }^{5}$ Os músicos eram Pirisca Grecco, Rafa e Texo Cabral.

BARBOZA, Mônica Corrêa de Borba; ALVES, Mara Rubia; GRECCO, Afonso Machado. A música como inspiração poética para a criação: relatos sobre a montagem do espetáculo "Dançar as coisas do Pago". Revista da FUNDARTE. Montenegro, p.189-214, ano 20, o 40, janeiro/março de 2020.

Disponível em: http://.seer.fundarte.rs.gov.br/index.php/RevistadaFundarte/index> 31 de março de 2020.
} 


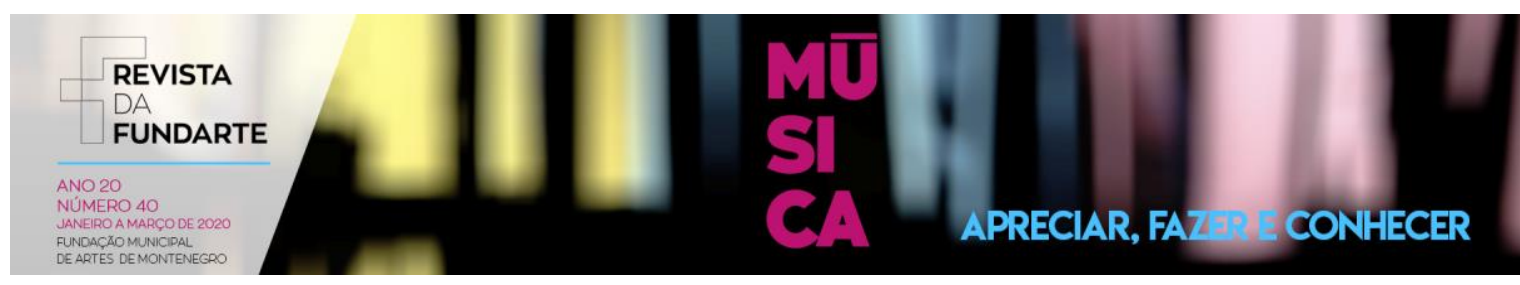

Para compor a segunda cena do espetáculo, "Fios que tecem a vida", realizamos experimentações com fios de cordão cru, buscando movimentos e estados corporais em torno da metáfora dos fios e do trabalho do crochê, como um ciclo de vida. Com esta intencionalidade inicial, utilizamos a canção "La Campana"6 em versão instrumental, inspirando-nos nas diferentes nuances que o arranjo trazia, repleto de sonoridades de instrumentos muito presentes nas canções regionais. Os movimentos e improvisações trazidos pelas bailarinas remeteram a seus afetos e acabaram por brincar com a "Cama de gato", unindo os fios. Dessa brincadeira vieram memórias e movimentos de outras brincadeiras, algumas desconhecidas das bailarinas mais novas. Vários desses elementos vieram para a cena, que foi toda estruturada a partir do instrumental. No caso desse procedimento em específico, a letra da Música, não foi utilizada aliás, a letra original não dialogava com a proposta da cena. Mas a versão instrumental foi extremamente instigante para a criação, levando-nos a outras imagens e movimentos.

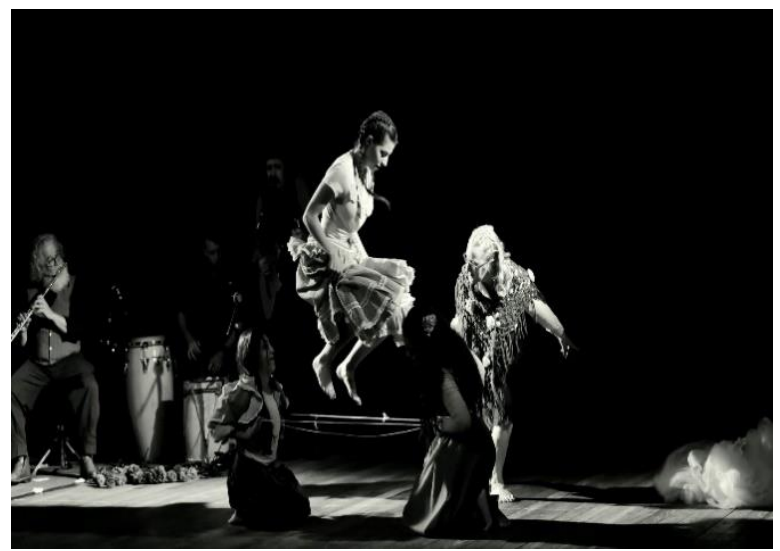

Figura 11: "Fios que tecem a vida"

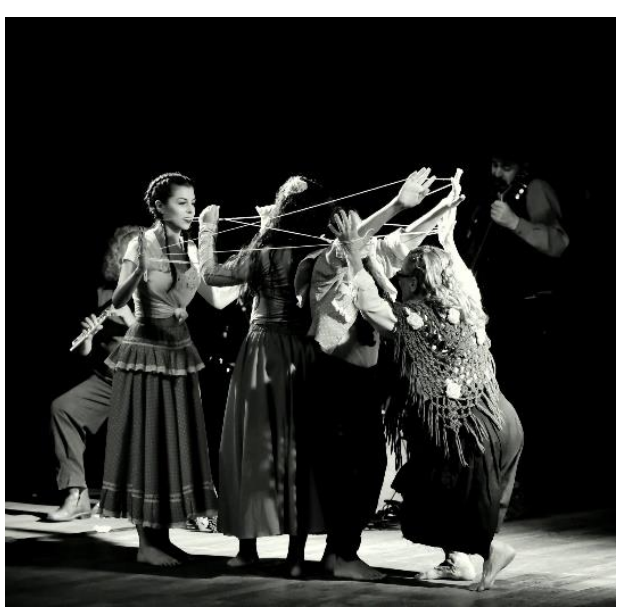

Figura 12:"Cama de gato"

Crédito das imagens: Joan Felipe Michel

\footnotetext{
${ }^{6}$ A canção é uma composição de Leonel Gomez e Evair Gomez. Utilizamos a versão instrumental que foi tema de abertura da Reculuta da Canção Crioula. Disponível em: https://www.youtube.com/watch?v=Vm86LcjFAys.

BARBOZA, Mônica Corrêa de Borba; ALVES, Mara Rubia; GRECCO, Afonso Machado. A música como inspiração poética para a criação: relatos sobre a montagem do espetáculo "Dançar as coisas do Pago". Revista da FUNDARTE. Montenegro, p.189-214, ano 20, o 40, janeiro/março de 2020.

Disponível em: http://.seer.fundarte.rs.gov.br/index.php/RevistadaFundarte/index> 31 de março de 2020.
} 


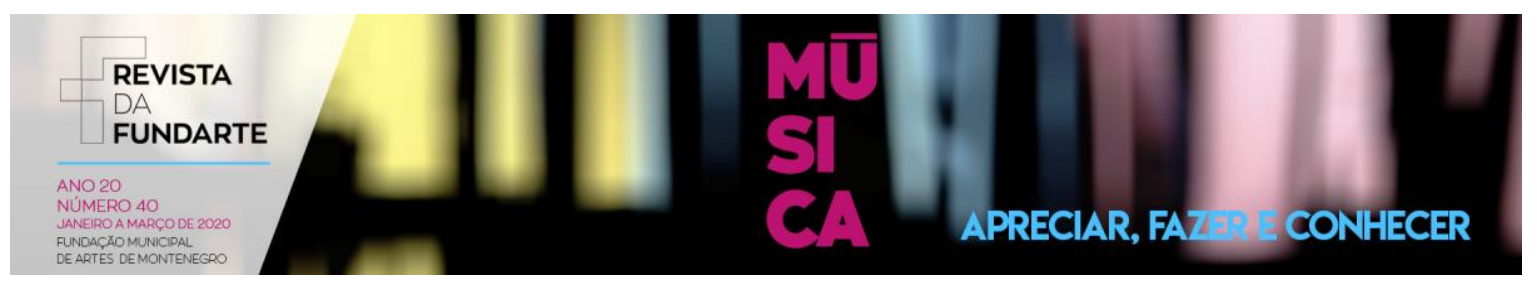

Ao chegarmos aos ensaios finais, afinávamos as inspirações que o artista musical havia composto, com as nossas propostas iniciais. Nas trocas que tínhamos, íamos pensando nas musicalidades que comporiam cada momento, ligação entre as cenas, etc. No ensaio geral, foi a primeira vez que todo elenco esteve junto, assim, bateirista e flautista também compunham a cena. Foi somente neste momento que os detalhes finais foram aprimorados. Então por exemplo, pudemos dançar a canção de Pirisca Grecco "Canta Maria", dançando a cidade, as tantas Marias que nos constituem e nossas vidas como obra de Arte. Ali, depois de toda proposta desenvolvida, os bailarinos e bailarinas lidaram com o ineditismo daquele momento e com a sensação única de dançar e tocar simultaneamente, ao vivo. Assim, o espetáculo trazia uma imprevisibilidade e, ao mesmo tempo, uma tranquilidade enormes, pois havia uma interdepência, uma troca constante entre sentir e atuar conjuntamente entre todo grupo.

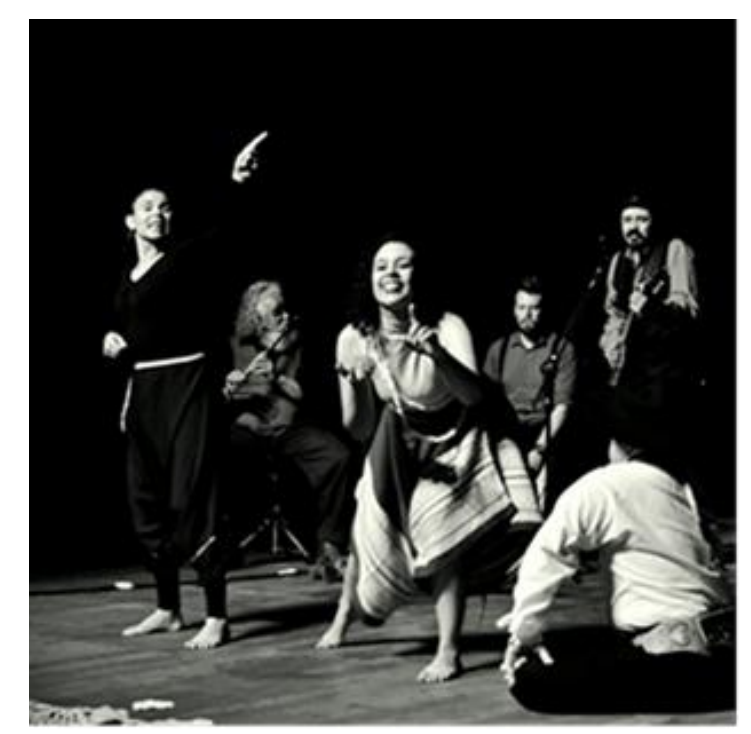

Figura 13: Músicos, Intérprete e bailarinos em Cena

Créditos da imagem: Dartanhan Baldez Figueiredo

BARBOZA, Mônica Corrêa de Borba; ALVES, Mara Rubia; GRECCO, Afonso Machado. A música como inspiração poética para a criação: relatos sobre a montagem do espetáculo "Dançar as coisas do Pago". Revista da FUNDARTE. Montenegro, p.189-214, ano 20, oㅡ 40, janeiro/março de 2020.

Disponível em: http://.seer.fundarte.rs.gov.br/index.php/RevistadaFundarte/index> 31 de março de 2020. 


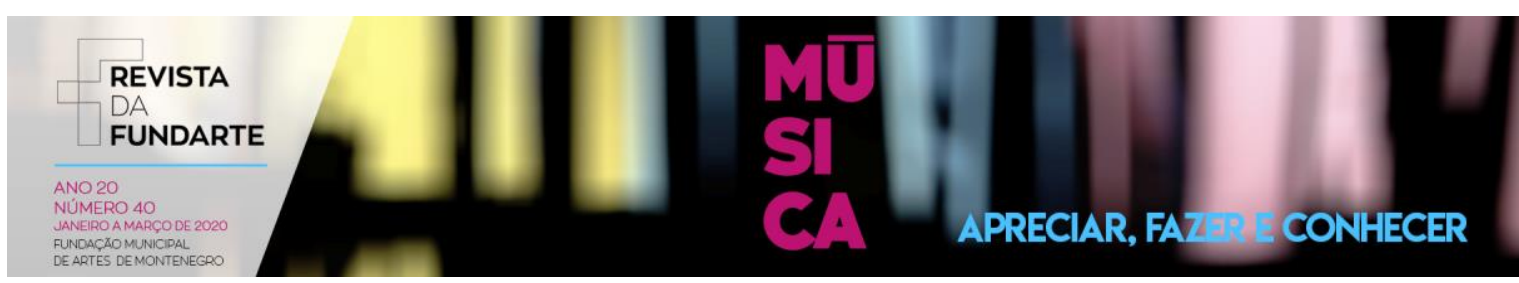

Muchas gracias é minha palavra"7... canções para seguir dançando... danças para seguir cantando...

O processo de criação como um todo foi para nós, um fazer coletivo em essência, desde de sua proposição de junção entre artistas da Música e da Dança. Pode parecer lugar comum dizer que foi uma experiência formativa extremamente enriquecedora, mas não podemos deixar de evidenciar e destacar a importância que a montagem teve em nosso desenvolvimento profissional. Os estudantes em formação inicial, sobretudo de cursos de licenciatura puderam aprimorar sua formação artístico-pedagógica, vivenciado aprendizagens que extrapolaram o ensino. Dessa forma, ensino, extensão e pesquisa estiveram a todo momento imbricadas oportunizando outras experiências muito diferentes daquelas propostas nas disciplinas formais. Corroboramos com a defesa de Bellochio (2003) que vem apontando a importância da articulação do tripé ensino, pesquisa e extensão na formação dos licenciados e licenciadas em Música. Assim como a estudiosa, entendemos que os profissionais que cursam uma licenciatura no campo da Música, precisam ser preparados para atuar "na vida em todas as suas dinâmicas constitutivas" (p. 21), em nossas palavras, precisam formar-se para ensinar a todos e a todas.

Do mesmo modo, os professores e as professoras de Dança, em nossa proposição precisam constituir-se como profissionais capazes de atuar em distintos contextos, produzindo Arte. Tanto licenciados e licenciadas em Música quanto em Dança, precisam ser, antes de tudo artistas. Artistas produtores de sua própria Arte, autores de suas próprias metodologias de ensino e criação. Não basta ser um artista para ensinar Arte, é evidente, mas sem ser artista não é possível ensiná-la, reiteramos. Nesta formação, tanto os conhecimentos pedagógicos quanto os conhecimentos artísticos se inter-relacionam, congregam, fundem, em um único

\footnotetext{
7 Utilizamos aqui uma frase da canção "Muchas Gracias" de autoria de Pirisca Grecco e Gujo Teixeira.

BARBOZA, Mônica Corrêa de Borba; ALVES, Mara Rubia; GRECCO, Afonso Machado. A música como inspiração poética para a criação: relatos sobre a montagem do espetáculo "Dançar as coisas do Pago". Revista da FUNDARTE. Montenegro, p.189-214, ano 20, o 40, janeiro/março de 2020.

Disponível em: http://seer.fundarte.rs.gov.br/index.php/RevistadaFundarte/index> 31 de março de 2020.
} 


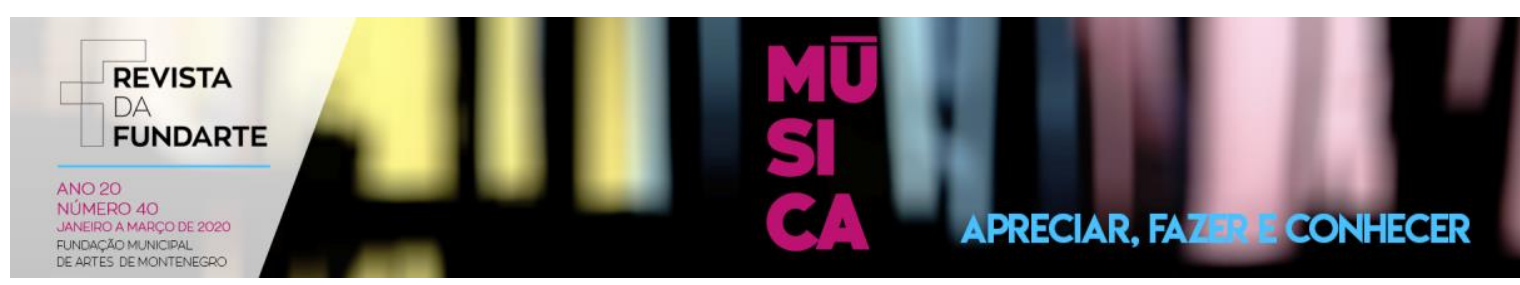

fazer. Por isso, oportunizar-lhes momentos e movimentos em que possam desenvolver suas potencialidades criativas e saberes inerentes à sua área de formação.

Cada bailarino e cada bailarina, como nos inspira Teixeira (2010), era, ali na cena, "um re-criador de si mesmo, um intérprete da falta, que se transfigura em movimentos, dança" (p. 41). E esta proposta, assim como a Dança Contemporânea, carregam a força para trabalhar a autonomia dos artistas e o encontro com suas próprias verdades artísticas.

Vários dos nossos bailarinos, fossem acadêmicos ou familiares dos artistas, estavam participando pela primeira vez de um processo de criação e de uma apresentação cênica, como afirmamos no texto. Traziam, em boa medida, a expectativa de que seriam "coreografados", recebendo sequências de movimentos a serem reproduzidas. No início das proposições tiveram certa dificuldade para atuar como intérpretes-criadores. Neste sentido, consideramos que a proposta de fazer as perguntas a partir da Música, favoreceu sobremaneira o trabalho. A maior parte dos bailarinos com deficiências já tinha trajetória longa de participação em projetos vinculados à Dança na universidade, e esta sua experiência auxiliou bastante, embora também tendessem em muitos momentos a certa "dependência" dos bailarinos sem deficiência, nos momentos de criação.

Para que pudesse realizar a Interpretação a tradução para a Língua Brasileira de Sinais, a intérprete e bailarina precisou de muitas trocas com o diretor musical. $O$ belo, neste caso, foi o fato de a menina ser carioca, e muitas vezes precisar de tradução de algumas analogias e expressões, além de ter que estudar sinais regionais que ela desconhecia, como de Sepé Tiaraju, por exemplo, herói gaúcho. Ao ouvir as canções e as transcrições, ela as ressignifica e conhecia, ao mesmo tempo.

Tanto as canções com letras quanto as instrumentais foram fundamentais para o processo de criação. Elas operaram como "perguntadoras" o que foi uma forma extremamente adequada e mobilizadora, para o perfil do grupo plural com 0 BARBOZA, Mônica Corrêa de Borba; ALVES, Mara Rubia; GRECCO, Afonso Machado. A música como inspiração poética para a criação: relatos sobre a montagem do espetáculo "Dançar as coisas do Pago". Revista da FUNDARTE. Montenegro, p.189-214, ano 20, no 40, janeiro/março de 2020.

Disponível em: http://seer.fundarte.rs.gov.br/index.php/RevistadaFundarte/index> 31 de março de 2020. 


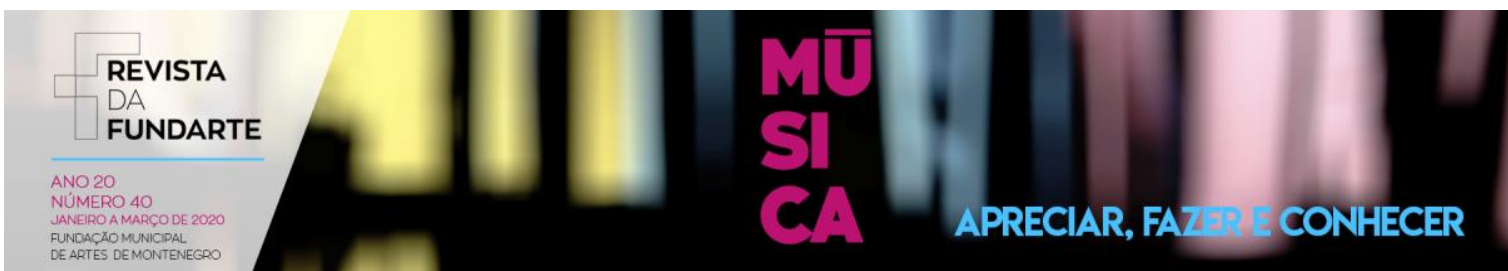

qual trabalhávamos. Comparando com experiências anteriores, em que havíamos trabalhado com outros procedimentos, percebemos o quanto os encaminhamentos utilizados neste processo em específico envolveu os artistas, facilitou o diálogo e instigou suas movimentações.

É importante destacar que nossa intenção não era a representação, ou a reprodução das Músicas de uma forma linear, mas sim trazer, de uma linguagem poética sonora, elementos hibridizados com as representações, vivências, sensações e emoções de cada artista. Criávamos assim, outras coisas, outras imagens, outros símbolos, outros sentidos. Nosso olhar sensível sobre nós mesmos, sobre ser e pertencer a este sul, compunham uma verdadeira colcha de crochê, tecida por várias mãos e histórias. Sem a Música seria diferente, seria muito diferente. Se o repertório e os artistas fossem outros também, obviamente. Mas, ao fim, concluíamos que a Música foi, não só uma provocação, foi uma inspiração e foi o espetáculo, uma vez estando presente em cena irmanada à Dança. As sensações, emoções, sentimentos, imagens e poesias instigadas pela Música foram, certamente nosso grande impulso criativo.

Embora tivéssemos a todo momento a intencionalidade de trabalhar a autonomia e instigar a autoria dos artitas, coube a nós o "amarrar" das cenas e da montagem. Como ressalta Teixeira (2010), ainda não temos tantos artistas com deficiência atuando como protagonistas, como condutores de grupos ou obras de Arte. Esta tem sido a militância da bailarina e tem sido também nossa tarefa como formadores e formadoras. Precisamos avançar cada vez mais em termos de políticas públicas que efetivamente oportunizem a todos e a todas o acesso, não só a fruição, mas ao estudo das distintas Artes.

Não só a temática desenvolvida em cena a partir do contexto gaúcho, como também, as sonoridades que compuseram o trabalho, envolveram sobremaneira os familiares dos artistas, especialmente os bailarinos do elenco que são de fora da universidade. A possibilidade de fruir um espetáculo de Dança e Música audiodescrito foi um aspecto muito ressaltado pelas pessoas com deficiência visual BARBOZA, Mônica Corrêa de Borba; ALVES, Mara Rubia; GRECCO, Afonso Machado. A música como inspiração poética para a criação: relatos sobre a montagem do espetáculo "Dançar as coisas do Pago". Revista da FUNDARTE. Montenegro, p.189-214, ano 20, no 40, janeiro/março de 2020.

Disponível em: http://seer.fundarte.rs.gov.br/index.php/RevistadaFundarte/index> 31 de março de 2020. 


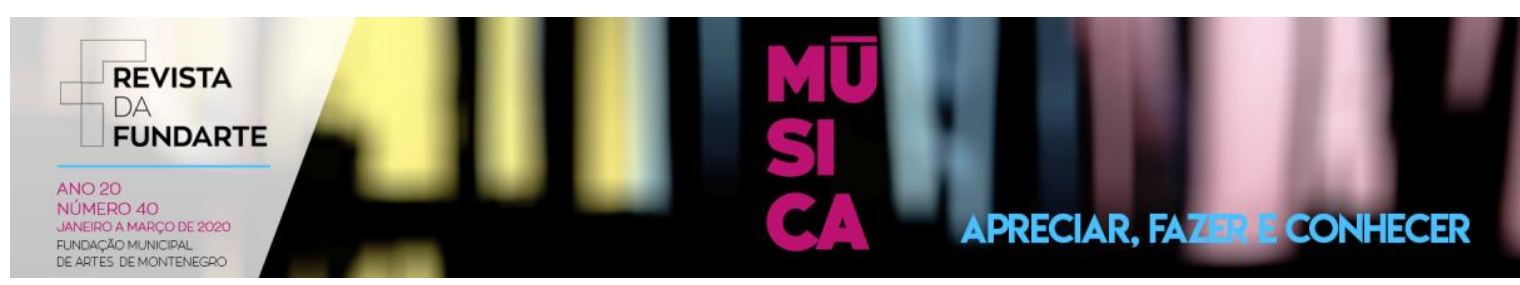

que estavam presentes. Para alguns, a primeira experiência deste tipo. Experiência repleta de sentidos e emoções narrados ao elenco ao fim da apresentação. Conhecer os elementos cênicos, tocar e sentir cada um dos instrumentos musiciais que compunham a cena, antes do espetáculo, através da visita guiada e audiodescrita, também foi um aspecto que os envolveu muito mais com o momento do espetáculo.

Quando relatam seus experimentos, Vieira e Avelino (2014) chegam a conclusão de que as distintas áreas da Música e da Dança, ao se encontrarem em sua proposta, propiciaram relações, "por vezes dialogando, harmonizando e se aproximando, mas também se afastando e se chocando" (p. 148). Diríamos que em nosso caso, dando-se as mãos, Dança e Música estiveram juntas a criar, aprender, ensinar e propor novas músicas dançadas e danças musicadas. Música como força, como grande ímpeto para compor Dança, nossas Danças e nossas velhas e novas históricas.

\section{Referências:}

BAUSCH, Pina. Dance senão estamos perdidos. Folha de São Paulo, São Paulo, 27/08/2000, p. 12.

BELLOCHIO, Cláudia Ribeiro. A formação profissional do educador musical: algumas apostas. Porto Alegre: Revista da ABEM, v.8., 17-24, mar. 2003.

BERTÉ, Odailso. Dança Contempop. Corpos, afetos e imagens (mo)vendo-se. Santa Maria: Ed. Da UFSM, 2015.

CROCO, Tonho; Trovadores. Intérprete: Ultramen. Peleia. In: Olelê. Gravadora Rockit!, 2000. 1 CD. Faixa 12.

DOMÍNIO PÚBLICO. Intérprete: Renato Borguetti. Prenda Minha. In: Gauderiando. Gravadora Atração Fonográfica, 1998. 1 CD. Faixa 2.

FERREIRA, Clarissa. Intérprete: Clarissa Ferreira. Manifesto Líquido. Disponível em: https://www.youtube.com/watch?v=H17vxkapfHI. Acesso em: 10 de fevereiro de 2019. GIBA, Giba; MESTRE, Xyco. Intérprete: Giba Giba. Outro Um. Quero Quero Produções

BARBOZA, Mônica Corrêa de Borba; ALVES, Mara Rubia; GRECCO, Afonso Machado. A música como inspiração poética para a criação: relatos sobre a montagem do espetáculo "Dançar as coisas do Pago". Revista da FUNDARTE. Montenegro, p.189-214, ano 20, no 40, janeiro/março de 2020.

Disponível em: http://seer.fundarte.rs.gov.br/index.php/RevistadaFundarte/index> 31 de março de 2020. 


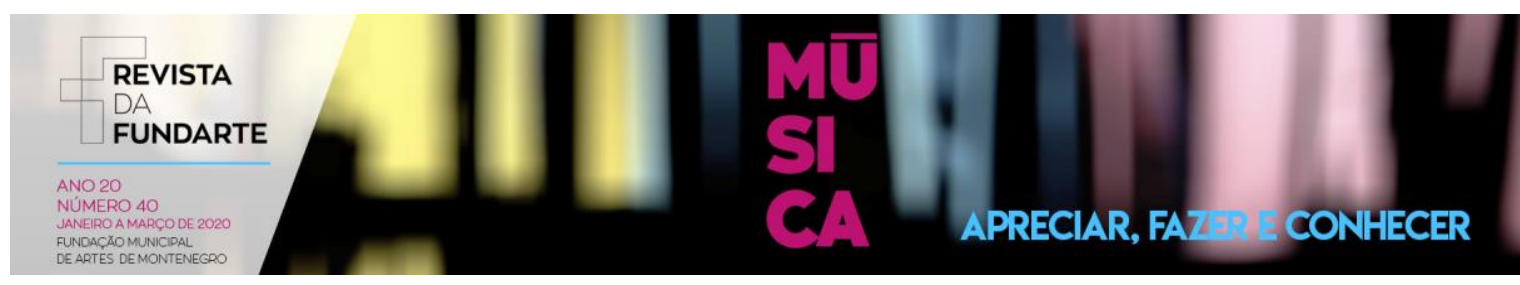

e Gravações, 1992. 1 LP. Faixa A1.

GOMEZ, Leonel; Gomez, Evair. La Campana. Disponível em:

https://www.youtube.com/watch?v=Vm86LcjFAys. Acesso em: 10 de fevereiro de 2019.

GRECCO, Pirisca; TEIXEIRA, Gujo. Intérprete: Pirisca Grecco. Muchas Gracias. In: Muchas Gracias. 2018 SangSongs, 2013. 1 CD. Faixa 14.

GRECCO, Pirisca. Intérprete: Comparsa Elétrica. Mandinga. In: Comparsa Elétrica. Gravadora USA RECORDS, 2013. 1 cd. Faixa 7.

- Intérprete: Pirisca Grecco. Zambita Nueva. In: Compasso Taipeiro. Gravadora Gadea, 2003. 1 CD. Faixa 13.

. Intérprete: Comparsa Elétrica. Canta Maria. In: Comparsa Elétrica. Gravadora USA RECORDS, 2013. $1 \mathrm{~cd}$. Faixa 11.

LESSA, Barbosa. Intérprete: Renato Borguetti. Negrinho do pastoreio. In: Gauderiando. Gravadora Atração Fonográfica, 1998. 1 CD. Faixa 3.

PASSOS, Juliana Cunha. Processo de criação em Dança: improvisação, sons e imagens. ANAIS DO IV ENCONTRO NACIONAL DE PESQUISADORES EM DANÇA. 2015.

RAMIL, Vitor. Intérprete: Vitor Ramil. Estrela, estrela. In: Foi no mês que vem. Gravadora Satolep Music, 2013. 1 CD. Faixa 3.

. Intérprete: Vitor Ramil. Chimarrão. In: Délibáb. Gravadora Satolep Music, 2010. 1 CD. Faixa 2.

Intérprete: Vitor Ramil. Querência. In: Longes. Gravadora Satolep

Music. 1 CD. Faixa 9.

ROCHA, Tereza. O que é Dança Contemporânea? A narrativa de uma possibilidade. Revista ENSAIO GERAL, Belém, v3, n.5, jan-jul, 2011.

SILVEIRA, Juliana Carvalho Franco da; MUNIZ, Mariana Lima. PINA BAUSCH E TANZTHEATER WUPPERTAL: processos de criação e dispositivos de composição. João Pessoa: Revista Moringa, v. 4. N.2, jul-dez, 2013.

TEIXEIRA, Ana Carolina Bezerra. Deficiência em cena: o corpo deficiente entre criações e subversões. Belém: Revista ENSAIO GERAL, Edição Especial, v.1, n.1,

BARBOZA, Mônica Corrêa de Borba; ALVES, Mara Rubia; GRECCO, Afonso Machado. A música como inspiração poética para a criação: relatos sobre a montagem do espetáculo "Dançar as coisas do Pago". Revista da FUNDARTE. Montenegro, p.189-214, ano 20, no 40, janeiro/março de 2020.

Disponível em: http://seer.fundarte.rs.gov.br/index.php/RevistadaFundarte/index> 31 de março de 2020. 


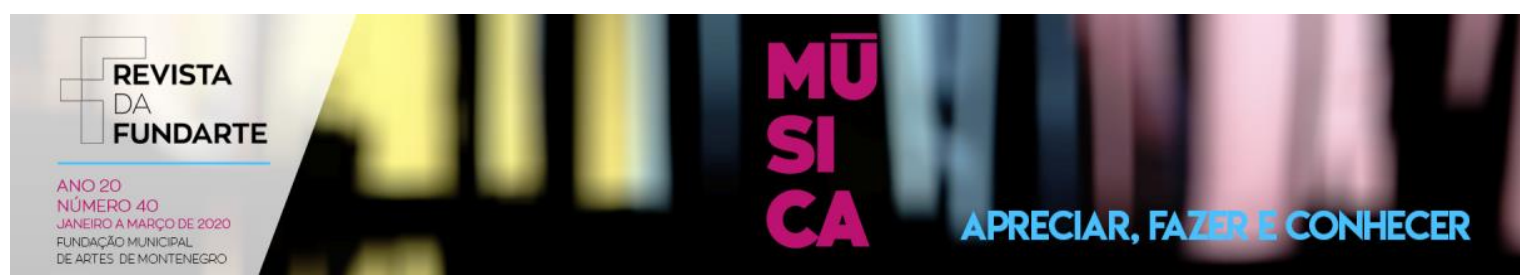

2010.

VIEIRA, Alba Pedreira; AVELINO, Dienifer Ribeiro. DANÇA, MÚSICA E PROCESSOS CRIATIVOS: posssíveis interfaces. João Pessoa: Revista Moringa, v. 5, n.2, julh-dez, 2014.

BARBOZA, Mônica Corrêa de Borba; ALVES, Mara Rubia; GRECCO, Afonso Machado. A música como inspiração poética para a criação: relatos sobre a montagem do espetáculo "Dançar as coisas do Pago". Revista da FUNDARTE. Montenegro, p.189-214, ano 20, o 40, janeiro/março de 2020.

Disponível em: http://.seer.fundarte.rs.gov.br/index.php/RevistadaFundarte/index> 31 de março de 2020. 